NIKOLAI ELECTROMAGNETIC AND MAGNETIC AIRBORNE GEOPHYSICAL SURVEY DATA COMPILATION

Burns, L.E., Graham, G.R.C., Barefoot, J.D., and Aerodat Inc.

Geophysical Report 2019-21

2020

STATE OF ALASKA

DEPARTMENT OF NATURAL RESOURCES

DIVISION OF GEOLOGICAL \& GEOPHYSICAL SURVEYS
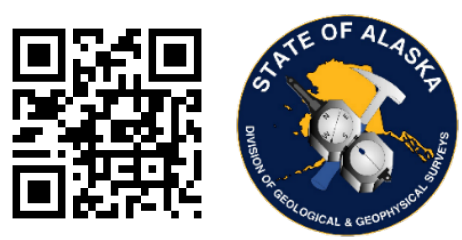
STATE OF ALASKA

Mike Dunleavy, Governor

\section{DEPARTMENT OF NATURAL RESOURCES}

Corri A. Feige, Commissioner

\section{DIVISION OF GEOLOGICAL \& GEOPHYSICAL SURVEYS}

Steve Masterman, State Geologist \& Director

Publications produced by the Division of Geological \& Geophysical Surveys are available to download from the DGGS website (dggs.alaska.gov). Publications on hard-copy or digital media can be examined or purchased in the Fairbanks office:

\section{Alaska Division of Geological \& Geophysical Surveys (DGGS) \\ 3354 College Road | Fairbanks, Alaska 99709-3707 \\ Phone: 907.451.5010 | Fax 907.451.5050 \\ dggspubs@alaska.gov | dggs.alaska.gov}

\section{DGGS publications are also available at:}

Alaska State Library, Historical

Collections \& Talking Book Center

395 Whittier Street

Juneau, Alaska 99801

Alaska Resource Library and

Information Services (ARLIS)

3150 C Street, Suite 100

Anchorage, Alaska 99503

\section{Suggested citation:}

Burns, L.E., Graham, G.R.C., Barefoot, J.D., a n d Aerodat Inc., 2020, Nikolai electromagnetic and magnetic airborne geophysical survey data compilation: Alaska Division of Geological \& Geophysical Surveys

Geophysical Report 2019-21. http://doi.org/10.14509/30262
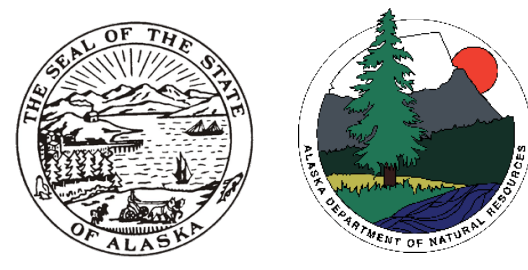


\title{
NIKOLAI ELECTROMAGNETIC AND MAGNETIC AIRBORNE GEOPHYSICAL SURVEY DATA COMPILATION
}

Burns, L.E.' , Graham, G.R.C. ', Barefoot, J.D. ', and Aerodat Inc.

\begin{abstract}
The Nikolai electromagnetic and magnetic airborne geophysical survey is located in interior Alaska in the Delta River mining district, about 200 kilometers southeast of Fairbanks. Frequency domain electromagnetic and magnetic data were collected with the Aerodat Condor system in 1995. A total of 3412.8 line kilometers were collected covering 660.1 square kilometers. Line spacing was 200 meters (m). Data were collected on a helicopter towed sensor platform ("bird") on a $30 \mathrm{~m}$ long line. The electromagnetic equipment recorded data slightly above $30 \mathrm{~m}$ above ground level (AGL), and the magnetometer recorded data slightly above $45 \mathrm{~m}$ AGL due to safety considerations. The Nikolai data were provided to DGGS by the U.S. Department of Interior Bureau of Land Management (BLM) and were merged with the Southern Delta River survey (2002) as a contract deliverable. The 2003 release of the Southern Delta River survey included map sheets of the merged data.
\end{abstract}

\section{PURPOSE}

This airborne geophysical survey is part of a program to acquire data on Alaska's most promising mineral belts and districts. The information acquired is aimed at catalyzing new private-sector exploration, discovery, and ultimate development and production. The purpose of the survey was to map the magnetic and conductive properties of the survey area. The survey area contains prospects for lode gold, placer gold, and Ni-Cu-PGE deposits. Other gold and base-metal anomalies, altered zones, favorable lithologies, and structural zones are known to exist throughout the survey area.

\section{SURVEY OVERVIEW DESCRIPTION}

This document provides an overview of the survey and includes text and figures of select primary and derivative products of this survey. A table of digital data packages available for download is provided to assist users in data selection. For reference, a catalog of the available maps is presented in reduced resolution. Please consult the metadata, project report, and digital data packages for more information and data.

\section{ACKNOWLEDGMENTS}

This survey was provided by the U.S. Department of Interior Bureau of Land Management (BLM) for publication with the 2002 Southern Delta River airborne geophysical survey.

\footnotetext{
${ }^{1}$ Alaska Division of Geological \& Geophysical Surveys, 3354 College Road, Fairbanks, Alaska 99709-3707
} 


\begin{tabular}{|c|c|c|}
\hline Data Type & Provider & Description \\
\hline ascii_data & contractor & ASCII format line data, other ASCII data \\
\hline databases_geosoft & contractor & $\begin{array}{l}\text { Geosoft format database of final line data, other } \\
\text { Geosoft format databases }\end{array}$ \\
\hline documents & contractor and DGGS & $\begin{array}{l}\text { Project and field reports, survey background } \\
\text { information, gridded data explanations, other } \\
\text { documentation }\end{array}$ \\
\hline grids_ermapper & contractor and DGGS & $\begin{array}{l}\text { Geographically registered gridded data, ER Mapper } \\
\text { ERS format }\end{array}$ \\
\hline grids_geosoft & contractor and DGGS & $\begin{array}{l}\text { Geosoft-format grids, these grids can be viewed in } \\
\text { ESRI ArcMap using a free plugin from Geosoft or the } \\
\text { free viewer available from Geosoft }\end{array}$ \\
\hline images_registered & DGGS & GeoTiff format images of all gridded data \\
\hline $\mathrm{kmz}$ & DGGS & $\begin{array}{l}\text { keyhole markup language }(\mathrm{kml}) \mathrm{kmz} \text { archive files of } \\
\text { project data. Viewable in Google Earth and other } \\
\text { compatible programs }\end{array}$ \\
\hline maps_pdf_format & contractor and DGGS & Printable maps in pdf format \\
\hline maps_prn_format & contractor & $\begin{array}{l}\text { Printable maps in HPGL/2 printer file format with } \\
\text { extension .prn }\end{array}$ \\
\hline profiles_stacked & contractor & $\begin{array}{l}\text { Distance-based profiles of the digitally recorded } \\
\text { geophysical data are generated and plotted at an } \\
\text { appropriate scale. The profiles display } \\
\text { electromagnetic anomalies with their respective } \\
\text { interpretive symbols. Printable in pdf format }\end{array}$ \\
\hline vector_data & contractor and DGGS & $\begin{array}{l}\text { Line path, data contours, and survey boundary in } \\
\text { ESRI shapefile (SHP) format, ESRI Geodatabase } \\
\text { format, and/or AutoCAD dxf format }\end{array}$ \\
\hline
\end{tabular}




\section{REFERENCES}

Akima, H., 1970, A new method of interpolation and smooth curve fitting based on local procedures: Journal of the Association of Computing Machinery, v. 17, n. 4, p. 589-602.

Burns, L.E., U.S. Bureau of Land Management, Fugro Airborne Surveys, and Stevens Exploration Management Corp., 2003, Line, grid, and vector data of airborne geophysical survey data for the southern Delta River area, east-central Alaska: Alaska Division of Geological \& Geophysical Surveys Geophysical Report 2003-6, 1 DVD. http://doi.org/10.14509/2973

Burns, L.E., U.S. Bureau of Land Management, Fugro Airborne Surveys, and Stevens Exploration Management Corp., 2003, Plot files of the airborne geophysical survey data of the southern Delta River area, east-central Alaska: Alaska Division of Geological \& Geophysical Surveys Geophysical Report 2003-5, 1 DVD. http://doi.org/10.14509/2904

Burns, L.E., and Clautice, K.H., 2003, Portfolio of aeromagnetic and resistivity maps of the southern Delta River area, east-central Alaska: Alaska Division of Geological \& Geophysical Surveys Geophysical Report 2003-8, 15 p. http://doi.org/10.14509/2975

Fraser, D.C., 1978, Resistivity mapping with an airborne multicoil electromagnetic system: Geophysics, v. 43, p. 144-172.

Pritchard, R.A., and Fugro Airborne Surveys, 2003, Project report of the airborne geophysical survey for the southern Delta River area, east-central Alaska: Alaska Division of Geological \& Geophysical Surveys Geophysical Report 2003-7, 252 p., 2 sheets, scale 1:63,360. http://doi.org/10.14509/2974 


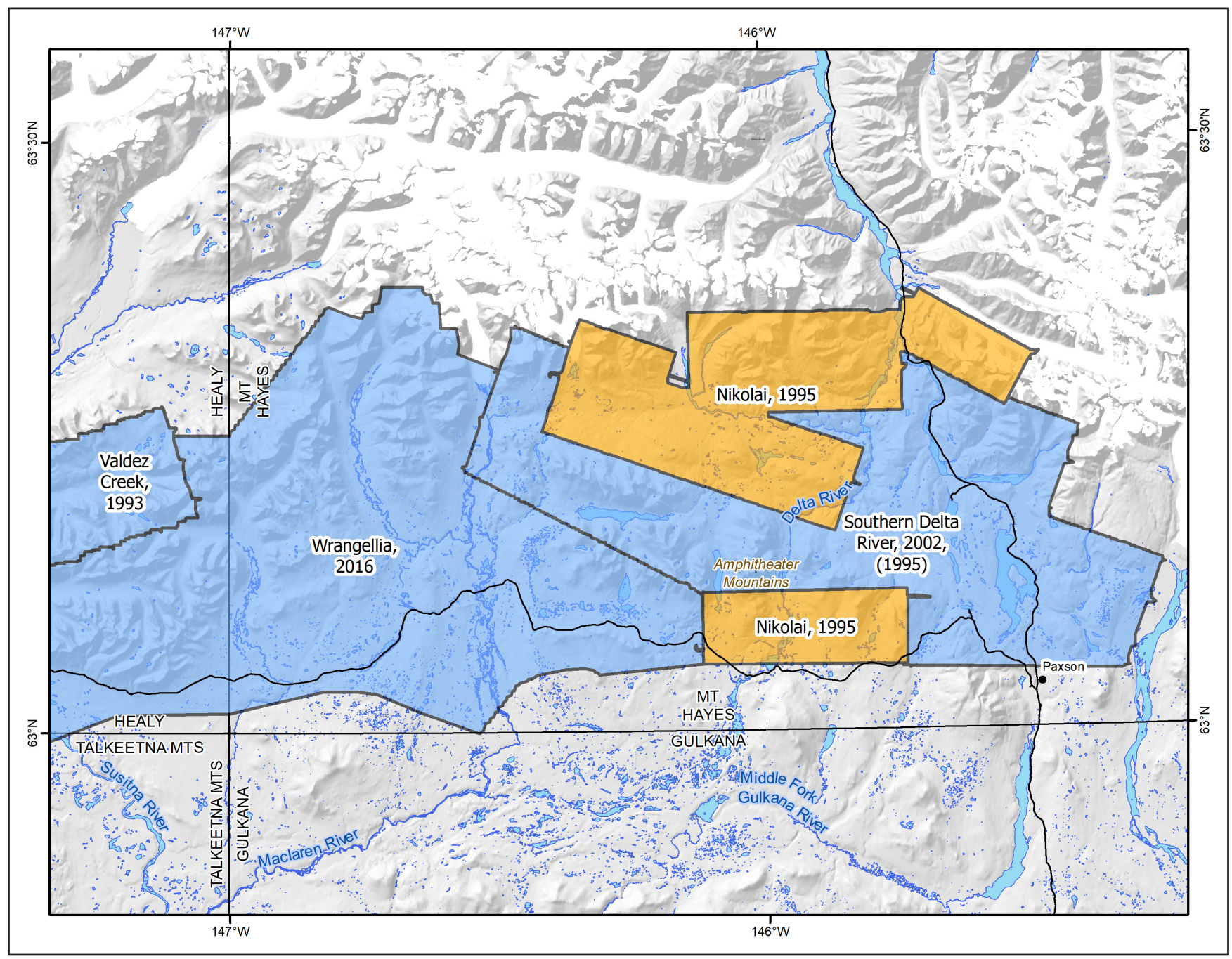

Figure 1. Nikolai electromagnetic and magnetic airborne geophysical survey location shown in interior Alaska (inset). Nikolai survey area shown with adjacent DGGS geophysical surveys, landmarks, relevant 1:250,000-scale quadrangle boundaries, mountain ranges, rivers, glaciers, and elevation hillshade.

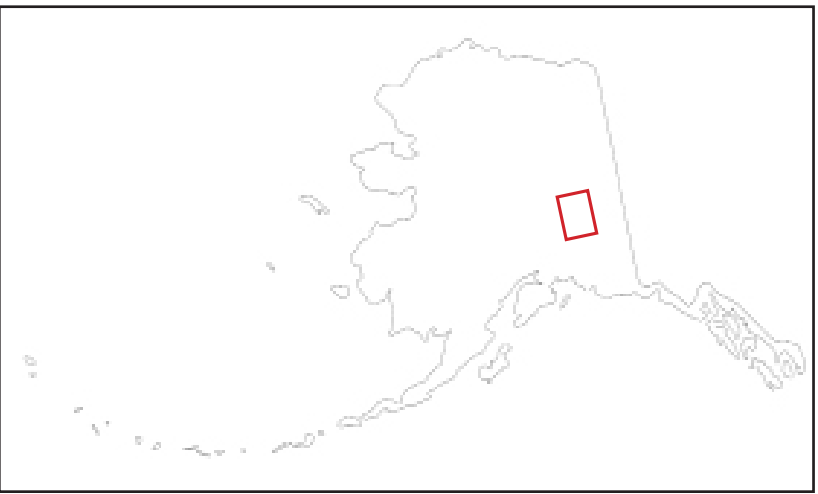




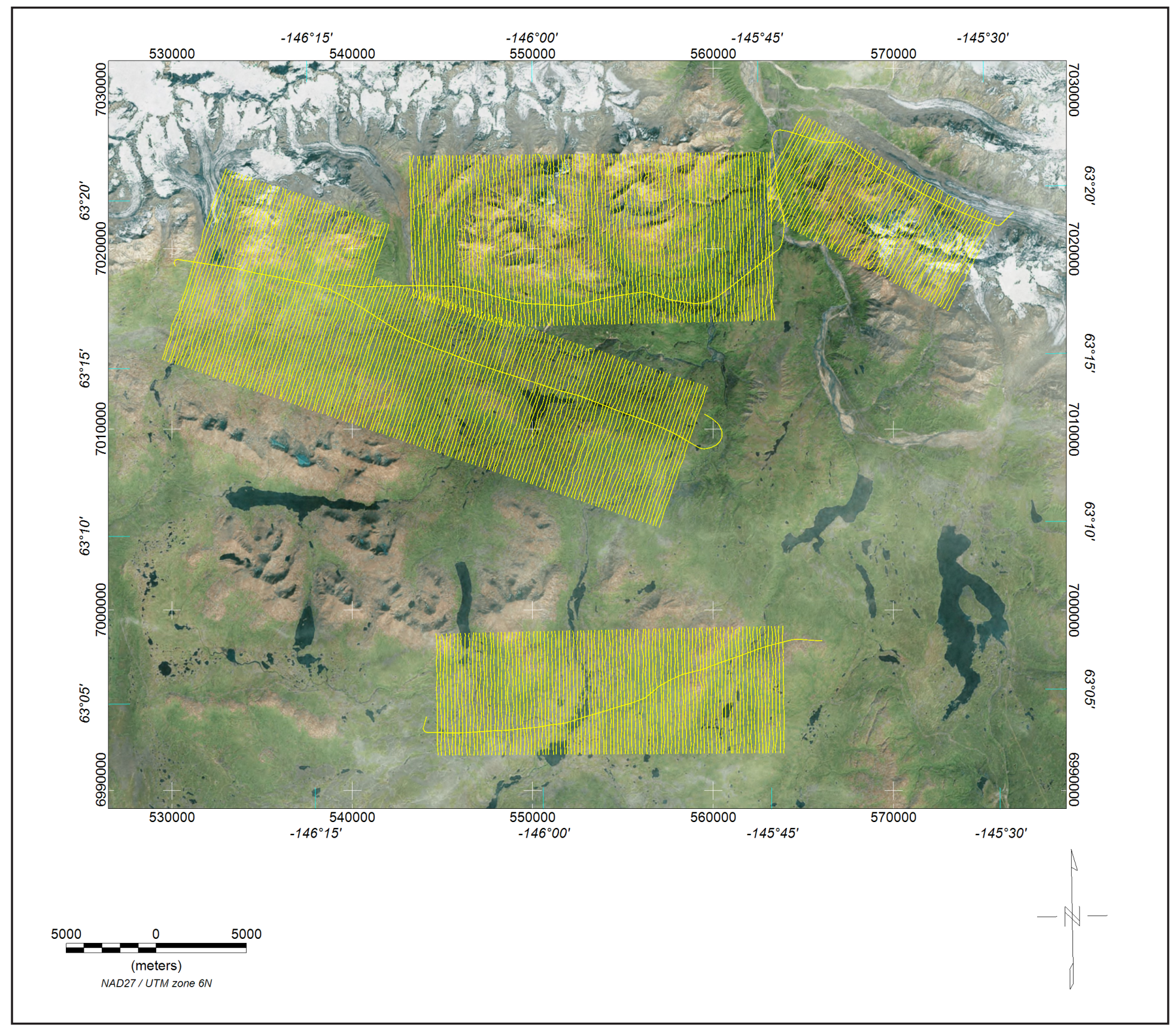

Figure 2. Flight path with orthometric image. 


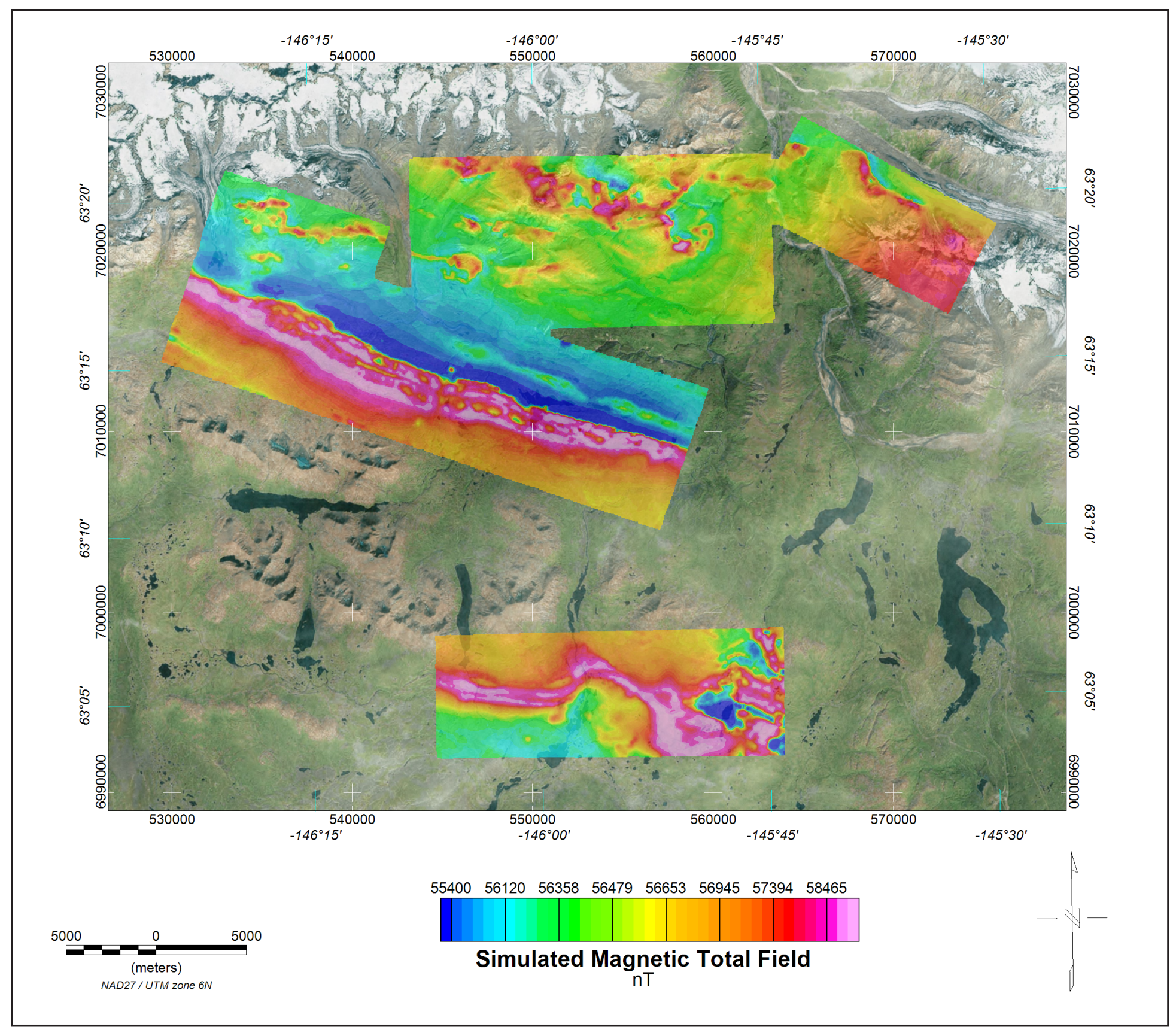

Figure 3. Simulated magnetic total field grid with orthometric image. The simulated magnetic total field data were created using digitally recorded data from a Scintrex cesium magnetometer. Data were collected at a sampling interval of 0.1 seconds. The magnetic data were (1) corrected for diurnal variations by subtracting the digitally recorded base station magnetic data, (2) IGRF corrected (IGRF model 2000, updated for date of flight and altimeter variations), (3) leveled to the tie line data, and (4) a constant value of approximately $57,000 \mathrm{nT}$ was added to all data. 


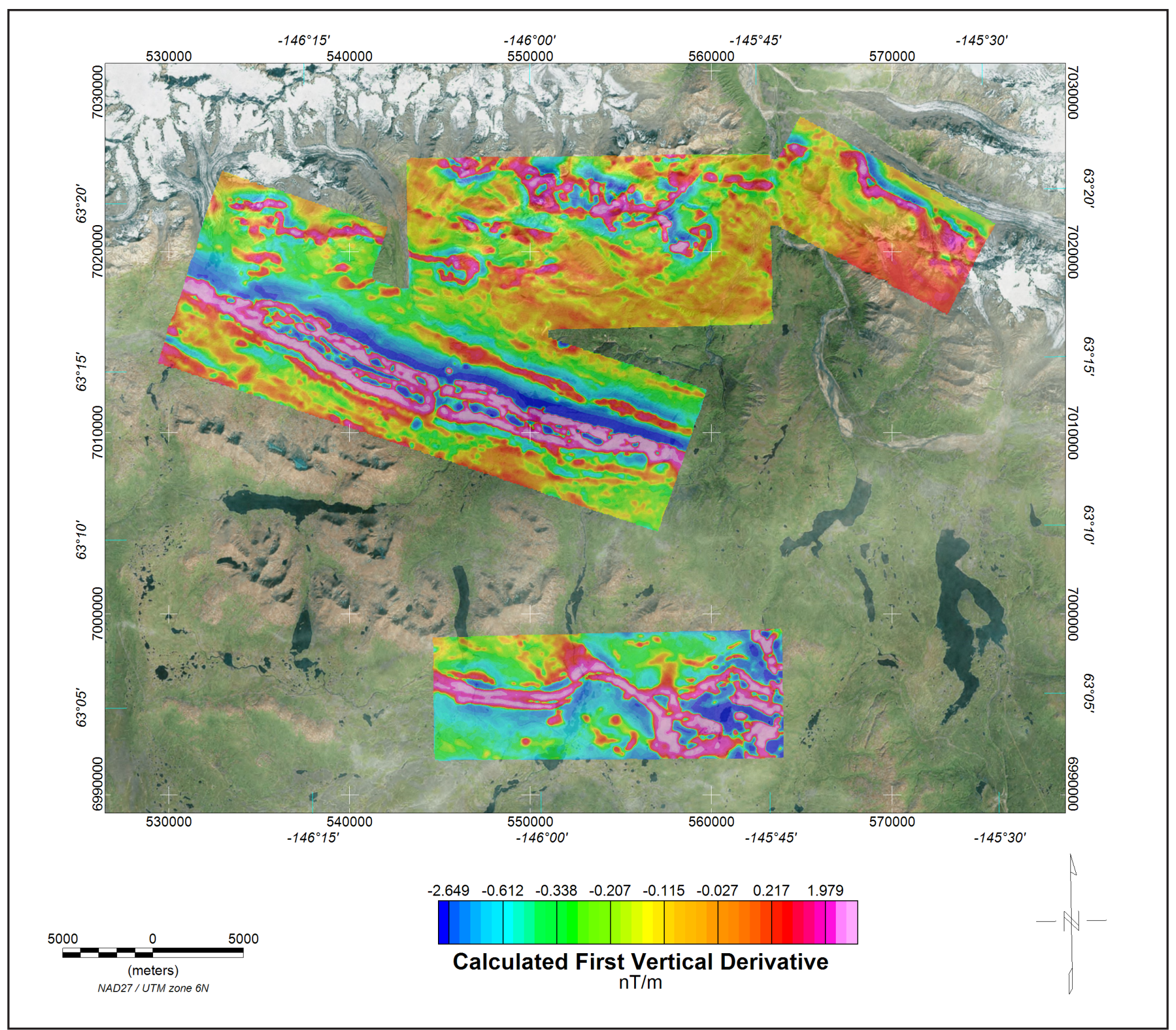

Figure 4. Calculated first vertical derivative grid with orthometric image. The first vertical derivative grid was calculated from the diurnally-corrected, IGRF-corrected total magnetic field grid using a FFT base frequency domain filtering algorithm. The resulting first vertical derivative grid provides better definition and resolution of near- surface magnetic units and helps to identify weak magnetic features that may not be evident on the total field data. 


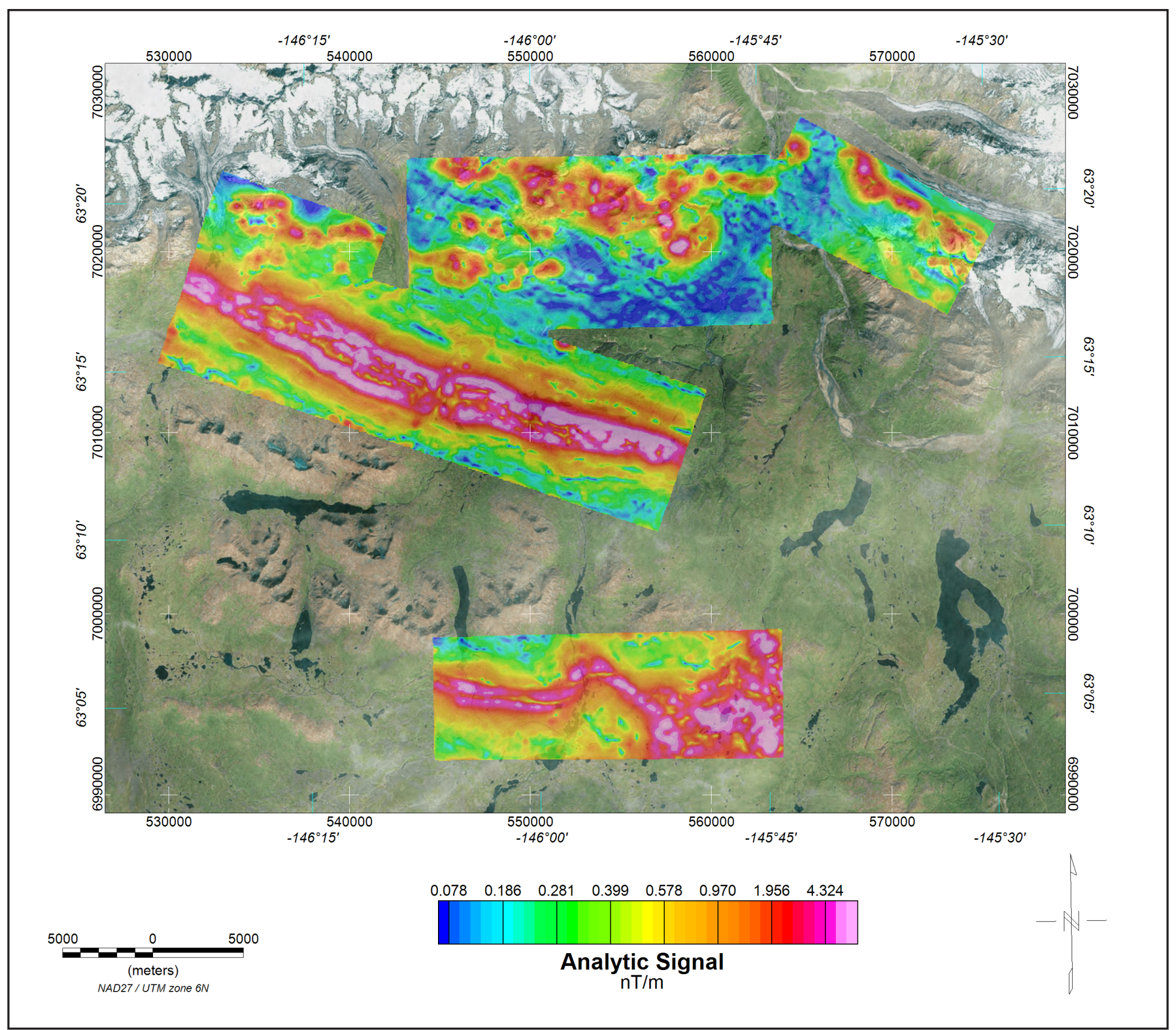

Figure 5. Analytic signal grid with orthometric image. Analytic signal is the total amplitude of all directions of magnetic gradient calculated from the sum of the squares of the three orthogonal gradients. Mapped highs in the calculated analytic signal of magnetic parameter locate the anomalous source body edges and corners (such as contacts, fault/shear zones, etc.). Analytic signal maxima are located directly over faults and contacts, regardless of structural dip, and independent of the direction of the induced and/or remanent magnetizations. 


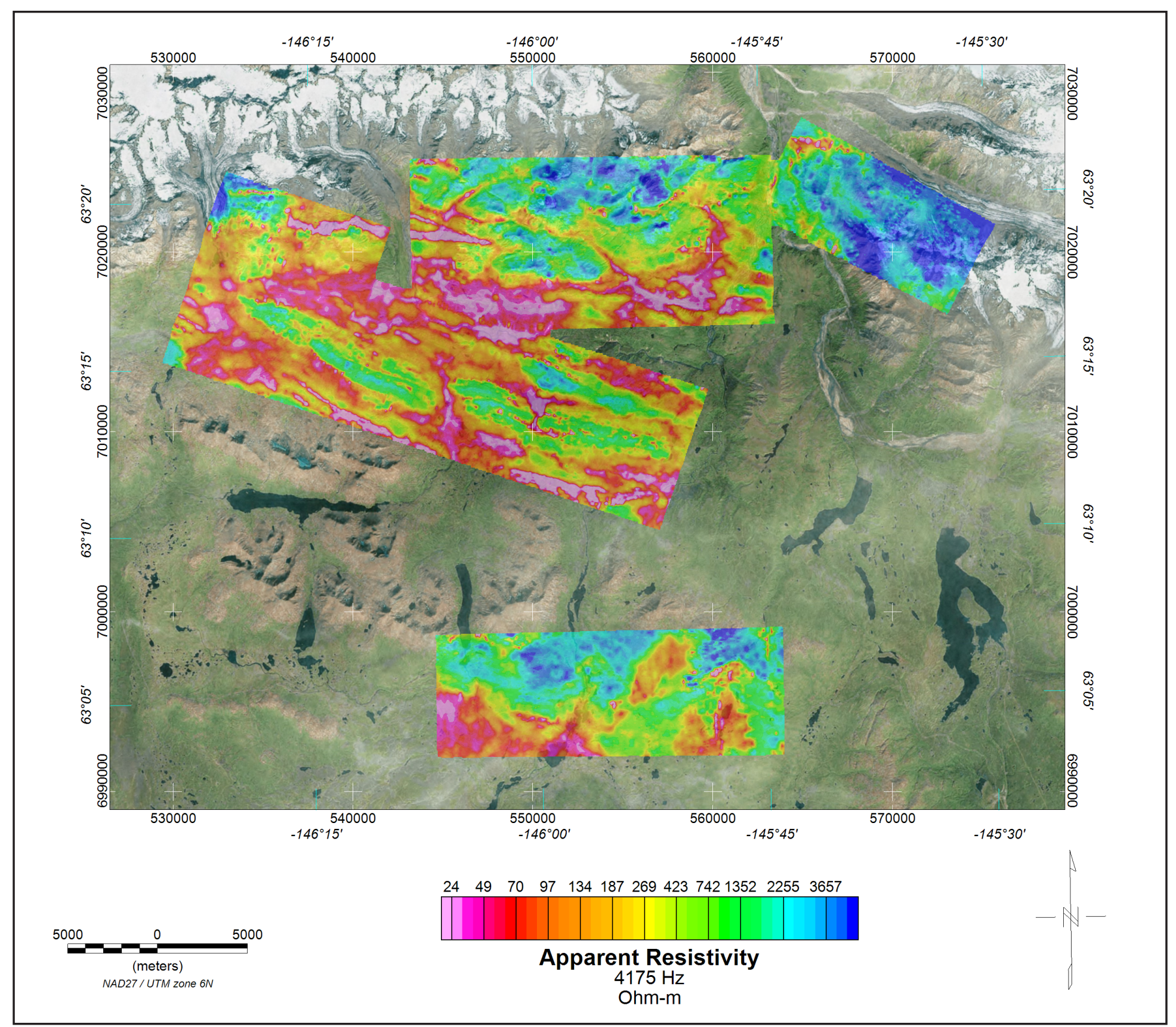

Figure 6. 4,175 Hz coplanar apparent resistivity grid with orthometric image. Analytic signal is the total amplitude of all directions of magnetic gradient calculated from the sum of the squares of the three orthogonal gradients. Mapped highs in the calculated analytic signal of magnetic parameter locate the anomalous source body edges and corners (such as contacts, fault/shear zones, etc.). Analytic signal maxima are located directly over faults and contacts, regardless of structural dip, and independent of the direction of the induced and/or remanent magnetizations. 


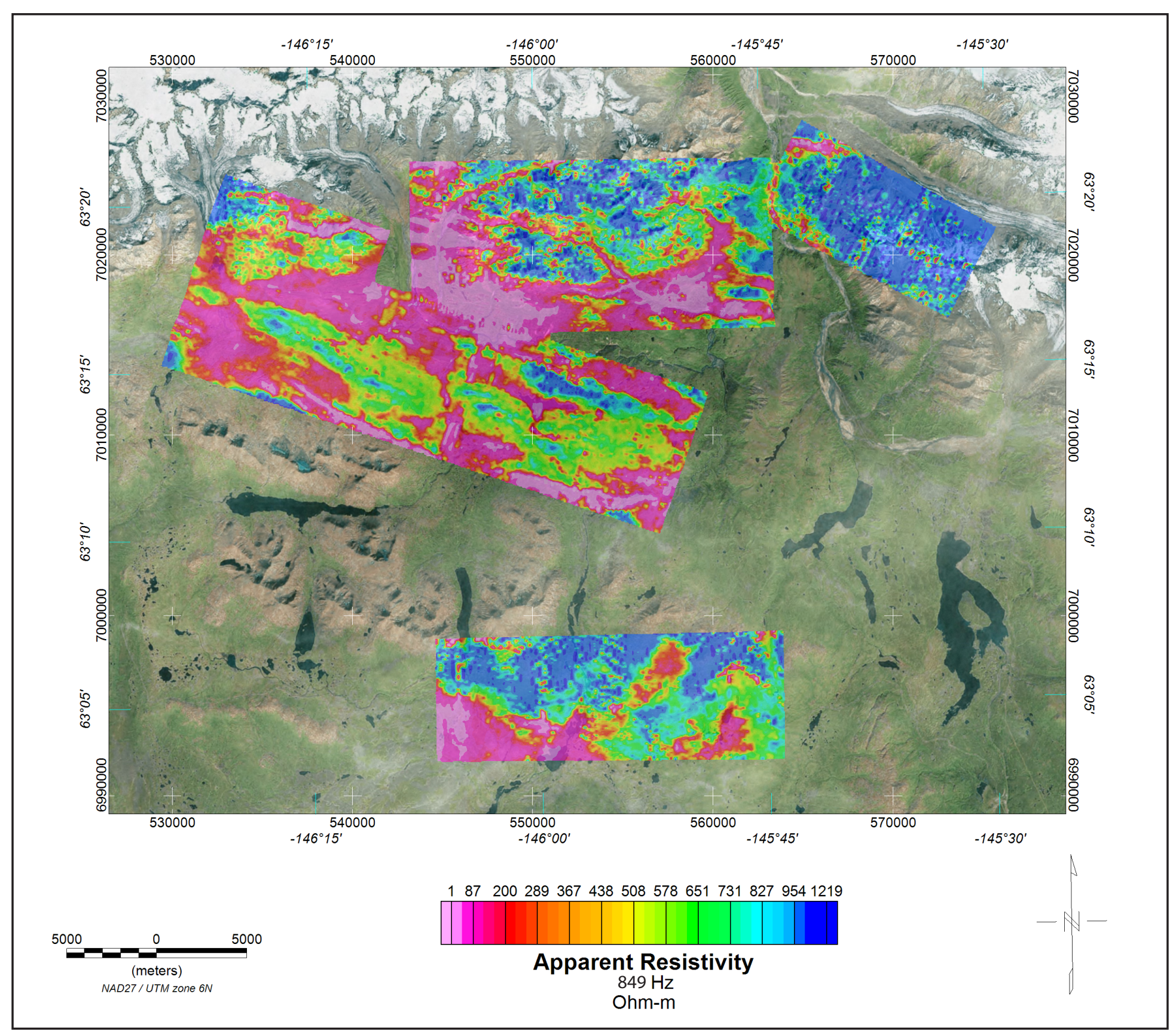

Figure 7. $849 \mathrm{~Hz}$ coplanar apparent resistivity grid with orthometric image. The Aerodat Condor EM system measured inphase and quadrature components at five frequencies. Two vertical coaxial coil-pairs operated at 936 and 4,476 Hz while three horizontal coplanar coil-pairs operated at 849, 4,189 and 32,490 Hz. EM data were sampled at 0.1 second intervals. The EM system responds to bedrock conductors, conductive overburden, and cultural sources. Apparent resistivity is generated from the inphase and quadrature component of the coplanar $845 \mathrm{~Hz}$ using the pseudo-layer half space model. 
Table 1. Copies of the following maps are included at the end of this booklet. The low-resolution, page-size maps included in this booklet are intended to be used as a search tool and are not the final product. Large-scale, full-resolution versions of each map are available to download on this publication's citation page: http://doi.org/10.14509/30262

\begin{tabular}{|c|c|}
\hline Map Title & Description \\
\hline southerndeltariver_flightlines_topo_map_1 of2.pdf & flightlines with topographic base map \\
\hline southerndeltariver_flightlines_topo_map_2of2.pdf & flightlines with topographic base map \\
\hline southerndeltariver_sim_magtf_topo_map_1of2.pdf & simulated magnetic total field grid with topographic base map \\
\hline southerndeltariver_sim_magtf_topo_map_2of2.pdf & simulated magnetic total field grid with topographic base map \\
\hline $\begin{array}{l}\text { southerndeltariver_sim_magtf_contours_plss_ } \\
\text { map_1of2.pdf }\end{array}$ & simulated magnetic total field grid with data contours and public land survey system base layer \\
\hline $\begin{array}{l}\text { southerndeltariver_sim_magtf_contours_plss_ } \\
\text { map_2of2.pdf }\end{array}$ & simulated magnetic total field grid with data contours and public land survey system base layer \\
\hline $\begin{array}{l}\text { southerndeltariver_sim_magtf_shaded_plss_ } \\
\text { map_1 of2.pdf }\end{array}$ & color shaded simulated total magnetic field grid with public land survey system base layer \\
\hline $\begin{array}{l}\text { southerndeltariver_sim_magtf_shaded_plss_ } \\
\text { map_2of2.pdf }\end{array}$ & color shaded simulated total magnetic field grid with public land survey system base layer \\
\hline southerndeltariver_res7200hz_topo_map_1of2.pdf & 7,200 Hz apparent resistivity grid with topographic base map \\
\hline southerndeltariver_res7200hz_topo_map_2of2.pdf & 7,200 Hz apparent resistivity grid with topographic base map \\
\hline $\begin{array}{l}\text { southerndeltariver_res } 7200 \mathrm{hz} \text { _contours_plss_ } \\
\text { map_1of2.pdf }\end{array}$ & 7,200 Hz apparent resistivity grid with data contours and public land survey system base layer \\
\hline $\begin{array}{l}\text { southerndeltariver_res } 7200 \mathrm{hz} \text { _contours_plss_ } \\
\text { map_2of2.pdf }\end{array}$ & 7,200 Hz apparent resistivity grid with data contours and public land survey system base layer \\
\hline $\begin{array}{l}\text { southerndeltariver_res7200hz_bw_contours_plss_ } \\
\text { map_1 of2.pdf }\end{array}$ & black and white $7,200 \mathrm{~Hz}$ apparent resistivity grid with data contours and public land survey system base layer \\
\hline $\begin{array}{l}\text { southerndeltariver_res7200hz_bw_contours_plss_ } \\
\text { map_2of2.pdf }\end{array}$ & black and white $7,200 \mathrm{~Hz}$ apparent resistivity grid with data contours and public land survey system base layer \\
\hline southerndeltariver_res900hz_topo_map_1 of2.pdf & $900 \mathrm{~Hz}$ apparent resistivity grid with topographic base map \\
\hline southerndeltariver_res900hz_topo_map_2of2.pdf & $901 \mathrm{~Hz}$ apparent resistivity grid with topographic base map \\
\hline $\begin{array}{l}\text { southerndeltariver_res } 900 \mathrm{hz} \text { _contours_plss_ } \\
\text { map_1 of2.pdf }\end{array}$ & $900 \mathrm{~Hz}$ apparent resistivity grid with data contours and public land survey system base layer \\
\hline $\begin{array}{l}\text { southerndeltariver_res } 900 \mathrm{hz} \text { _contours_plss_ } \\
\text { map_2of2.pdf }\end{array}$ & $901 \mathrm{~Hz}$ apparent resistivity grid with data contours and public land survey system base layer \\
\hline
\end{tabular}


Table 1, continued. Copies of the following maps are included at the end of this booklet. The low-resolution, page-size maps included in this booklet are intended to be used as a search tool and are not the final product. Large-scale, full-resolution versions of each map are available to download on this publication's citation page: http://doi.org/10.14509/30262

\begin{tabular}{|c|c|}
\hline Map Title & Description \\
\hline $\begin{array}{l}\text { southerndeltariver_res } 900 \mathrm{hz} \text { _bw_contours_plss_ } \\
\text { map_1 of2.pdf }\end{array}$ & black and white $900 \mathrm{~Hz}$ apparent resistivity grid with data contours and public land survey system base layer \\
\hline $\begin{array}{l}\text { southerndeltariver_res900hz_bw_contours_plss_ } \\
\text { map_2of2.pdf }\end{array}$ & black and white $900 \mathrm{~Hz}$ apparent resistivity grid with data contours and public land survey system base layer \\
\hline $\begin{array}{l}\text { southerndeltariver_emanomalies_sim_magtf_con- } \\
\text { tours_plss_map_1of2.pdf }\end{array}$ & em anomalies with simulated total magnetic field grid data contours and public land survey system base layer \\
\hline $\begin{array}{l}\text { southerndeltariver_emanomalies_sim_magtf_con- } \\
\text { tours_plss_map_2of2.pdf }\end{array}$ & em anomalies with simulated total magnetic field grid data contours and public land survey system base layer \\
\hline $\begin{array}{l}\text { southerndeltariver_emanomalies_sim_magtf_con- } \\
\text { tours_detailed_topo_map_1of7.pdf }\end{array}$ & detailed em anomalies with simulated total magnetic field grid data contours and topographic base map \\
\hline $\begin{array}{l}\text { southerndeltariver_emanomalies_sim_magtf_con- } \\
\text { tours_detailed_topo_map_2of7.pdf }\end{array}$ & detailed em anomalies with simulated total magnetic field grid data contours and topographic base map \\
\hline $\begin{array}{l}\text { southerndeltariver_emanomalies_sim_magtf_con- } \\
\text { tours_detailed_topo_map_3of7.pdf }\end{array}$ & detailed em anomalies with simulated total magnetic field grid data contours and topographic base map \\
\hline $\begin{array}{l}\text { southerndeltariver_emanomalies_sim_magtf_con- } \\
\text { tours_detailed_topo_map_4of7.pdf }\end{array}$ & detailed em anomalies with simulated total magnetic field grid data contours and topographic base map \\
\hline $\begin{array}{l}\text { southerndeltariver_emanomalies_sim_magtf_con- } \\
\text { tours_detailed_topo_map_5of7.pdf }\end{array}$ & detailed em anomalies with simulated total magnetic field grid data contours and topographic base map \\
\hline $\begin{array}{l}\text { southerndeltariver_emanomalies_sim_magtf_con- } \\
\text { tours_detailed_topo_map_6of7.pdf }\end{array}$ & detailed em anomalies with simulated total magnetic field grid data contours and topographic base map \\
\hline $\begin{array}{l}\text { southerndeltariver_emanomalies_sim_magtf_con- } \\
\text { tours_detailed_topo_map_7of7.pdf }\end{array}$ & detailed em anomalies with simulated total magnetic field grid data contours and topographic base map \\
\hline southerndeltariver_interpretation_plss_map_1of2.pdf & interpretation with public land survey system base layer \\
\hline southerndeltariver_interpretation_plss_map_2of2.pdf & interpretation with public land survey system base layer \\
\hline $\begin{array}{l}\text { southerndeltariver_dem_contours_plss_map_1 of2. } \\
\text { pdf }\end{array}$ & digital elevation grid with contours and public land survey system base layer \\
\hline $\begin{array}{l}\text { southerndeltariver_dem_contours_plss_map_2of2. } \\
\text { pdf }\end{array}$ & digital elevation grid with contours and public land survey system base layer \\
\hline
\end{tabular}




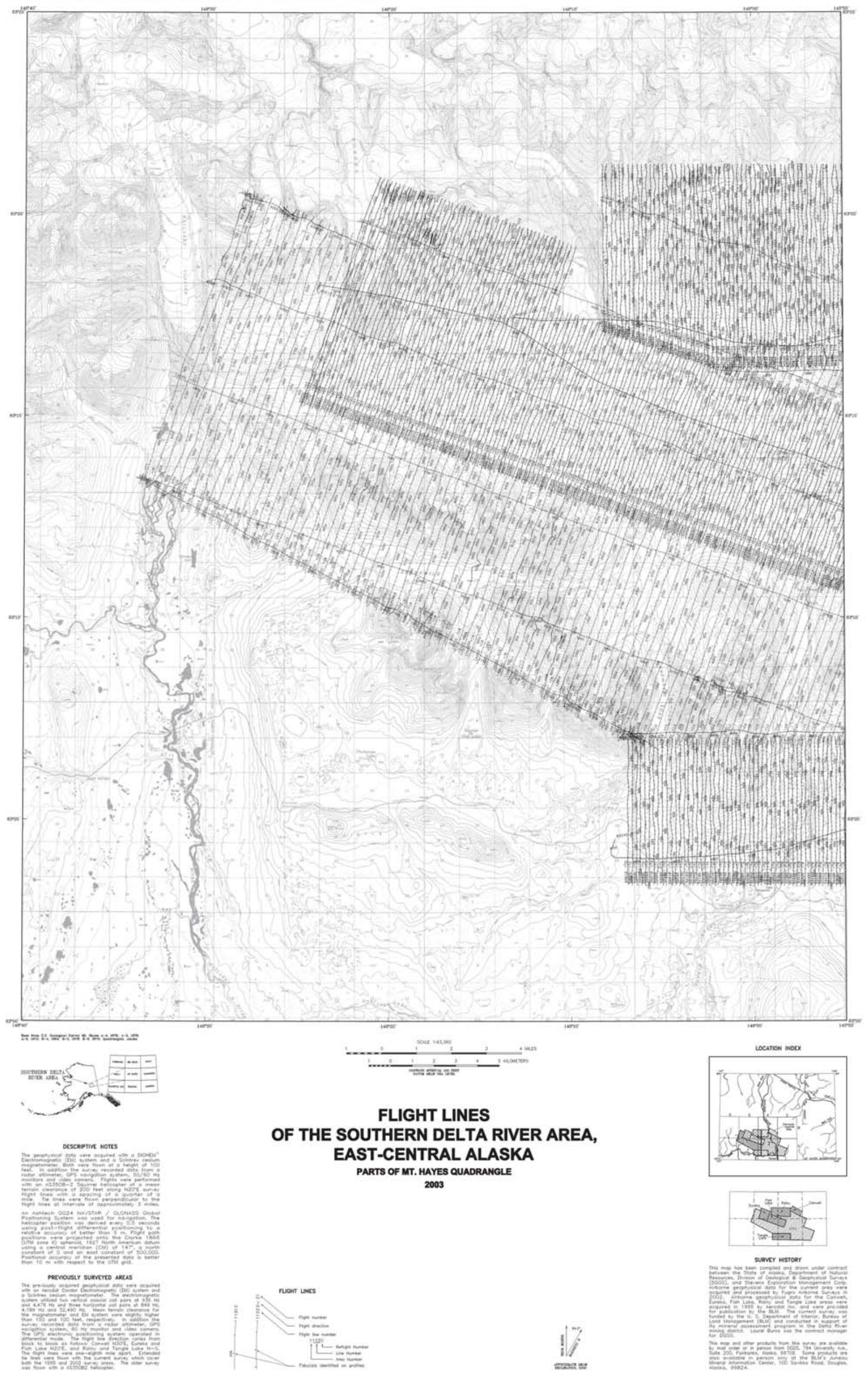




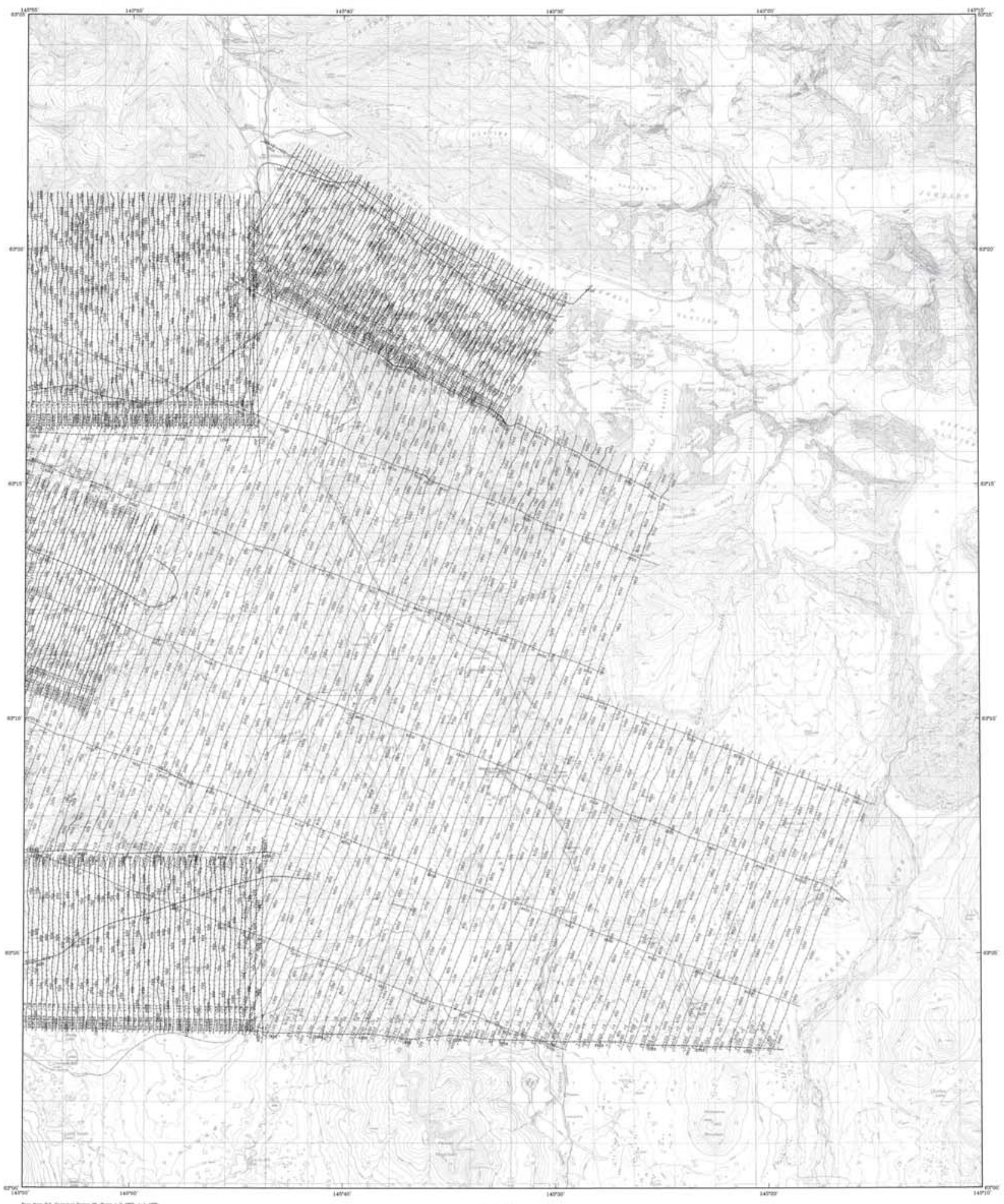

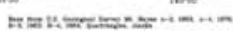
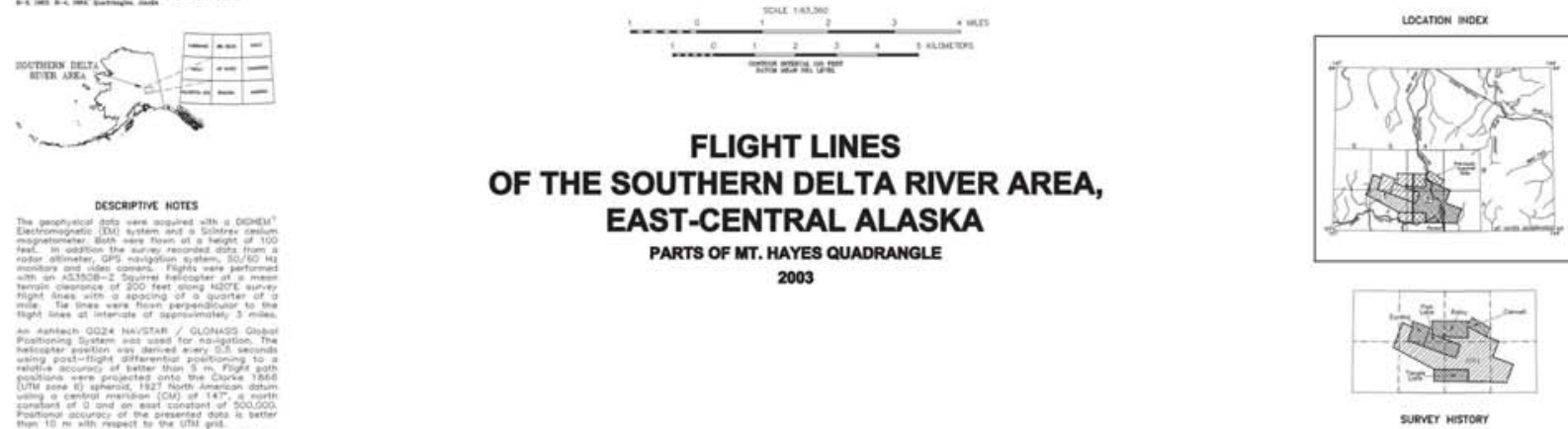

2003
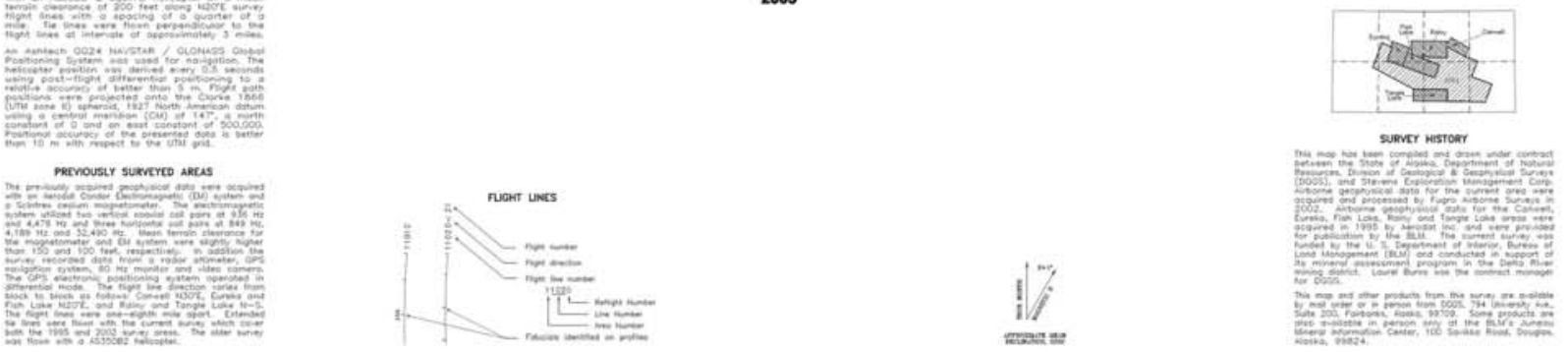


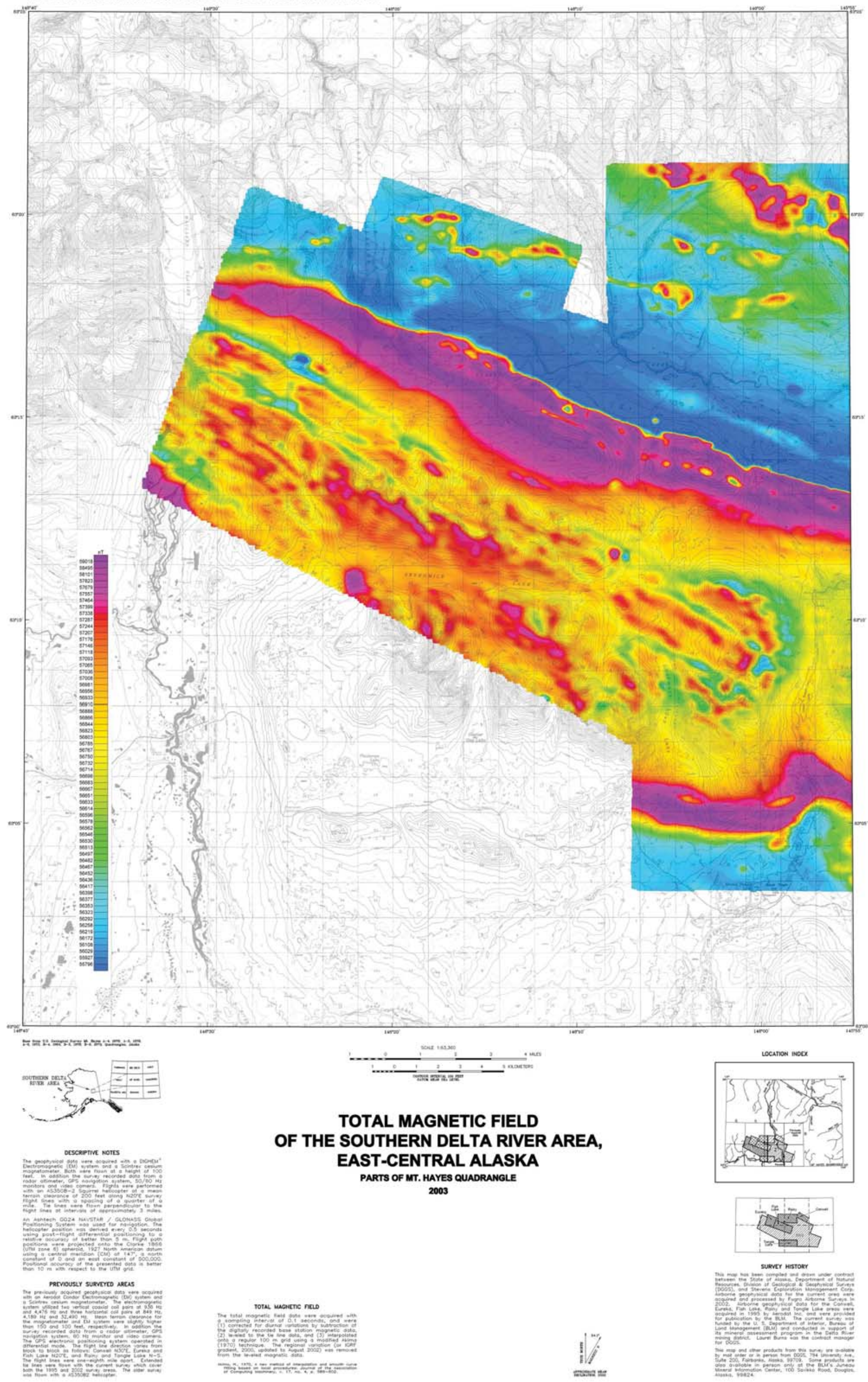




$\begin{array}{ll}\text { ALASKA DIVISION OF GEOLOGICAL \& GEOPHYSICAL SURVEYS } & \text { GEOPHYSICAL REPORT } 2003 \text {. } 5 \text {-1a } \\ \text { IN COOPERATION WITH THE U.S. BUREAU OF LAND MANAGEMENT } & \text { Shot } 2\end{array}$

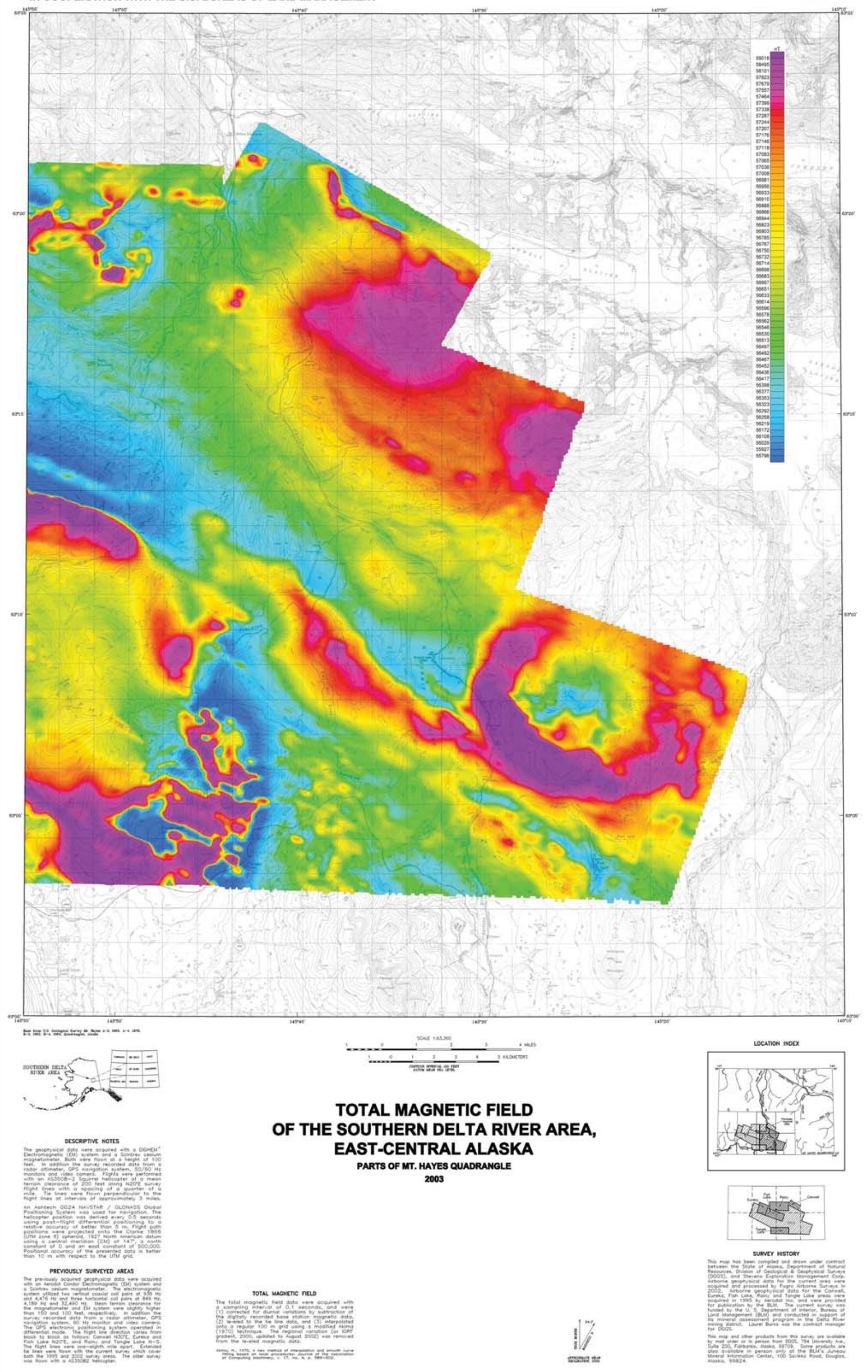




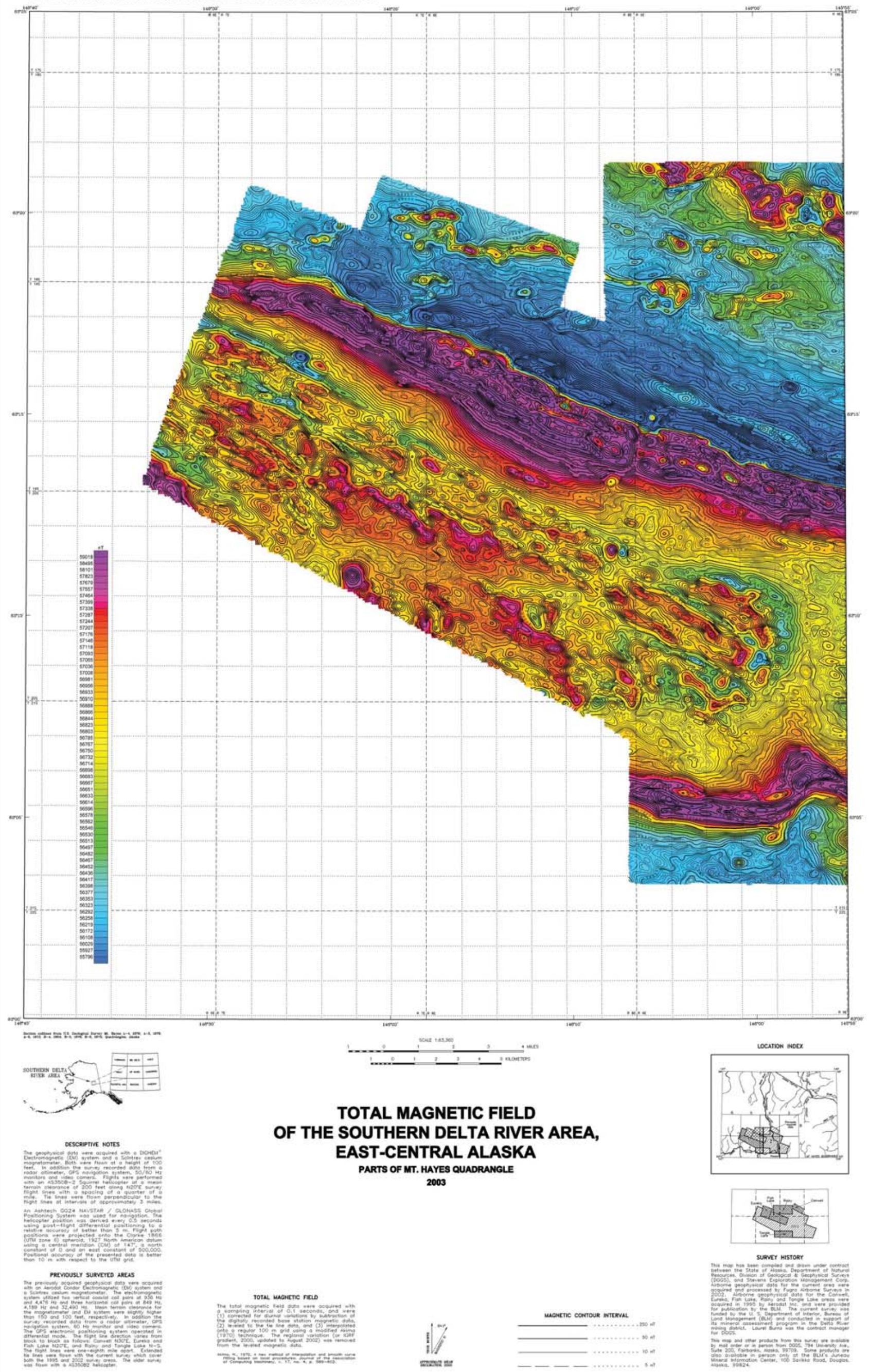




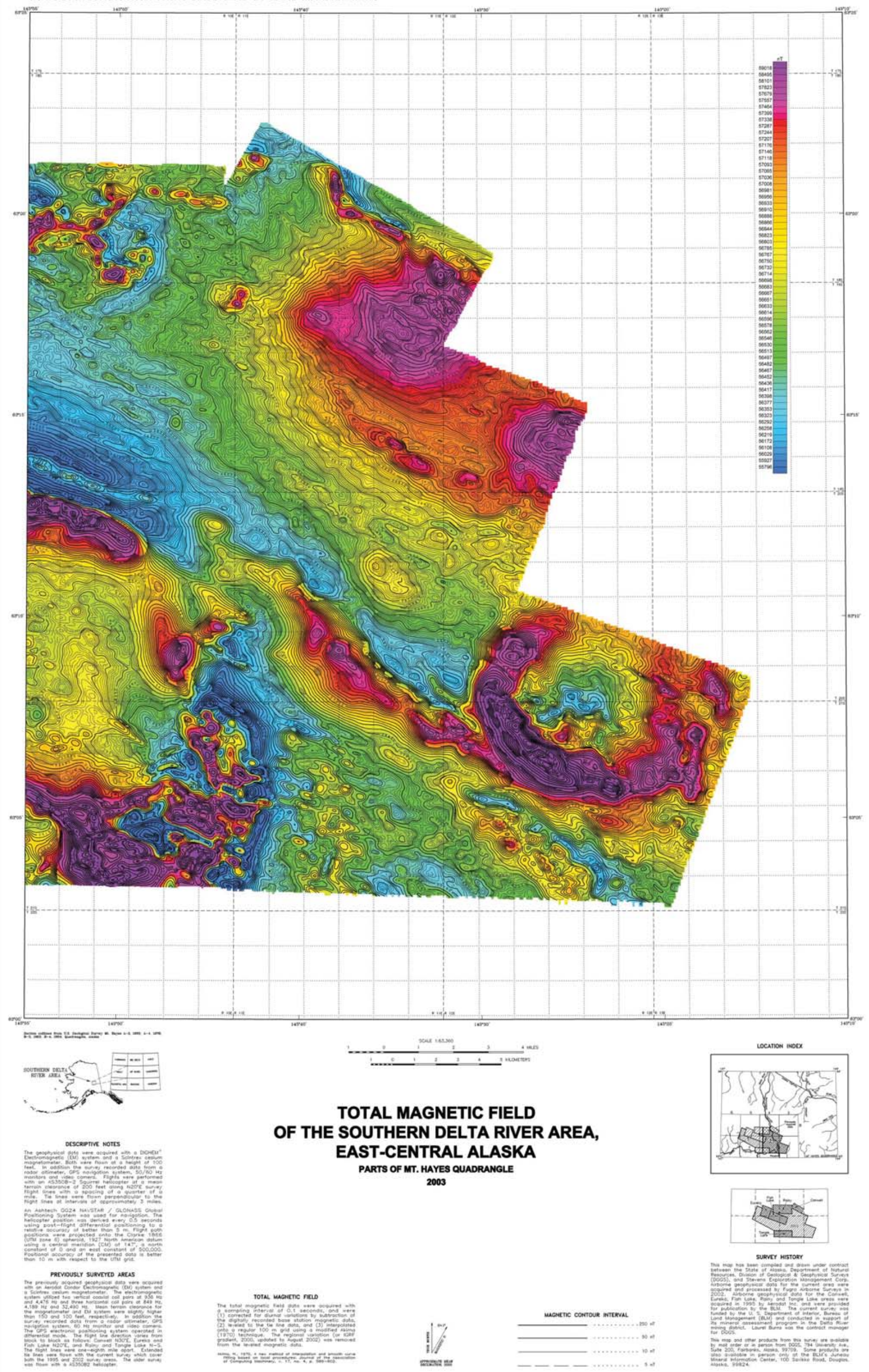




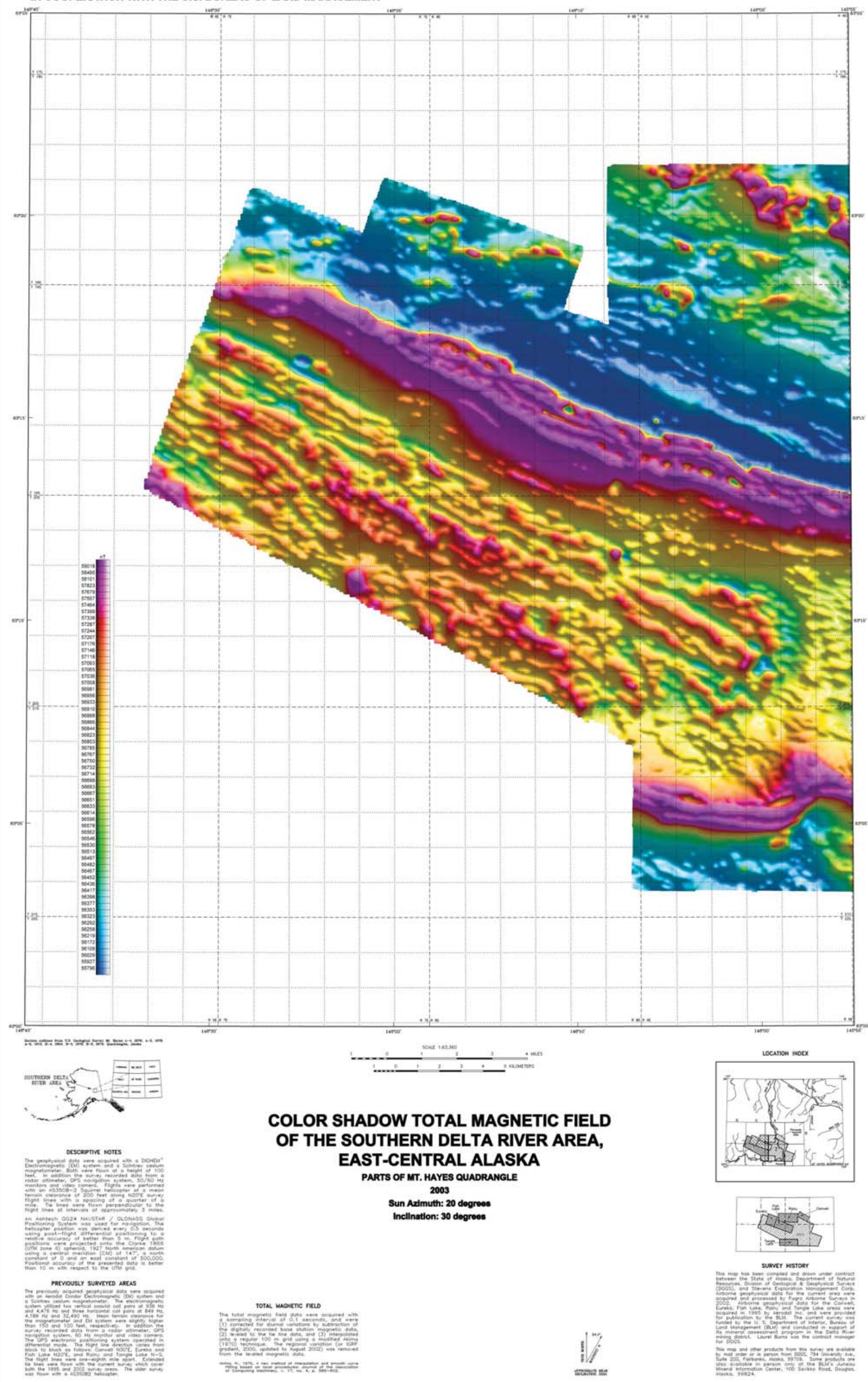




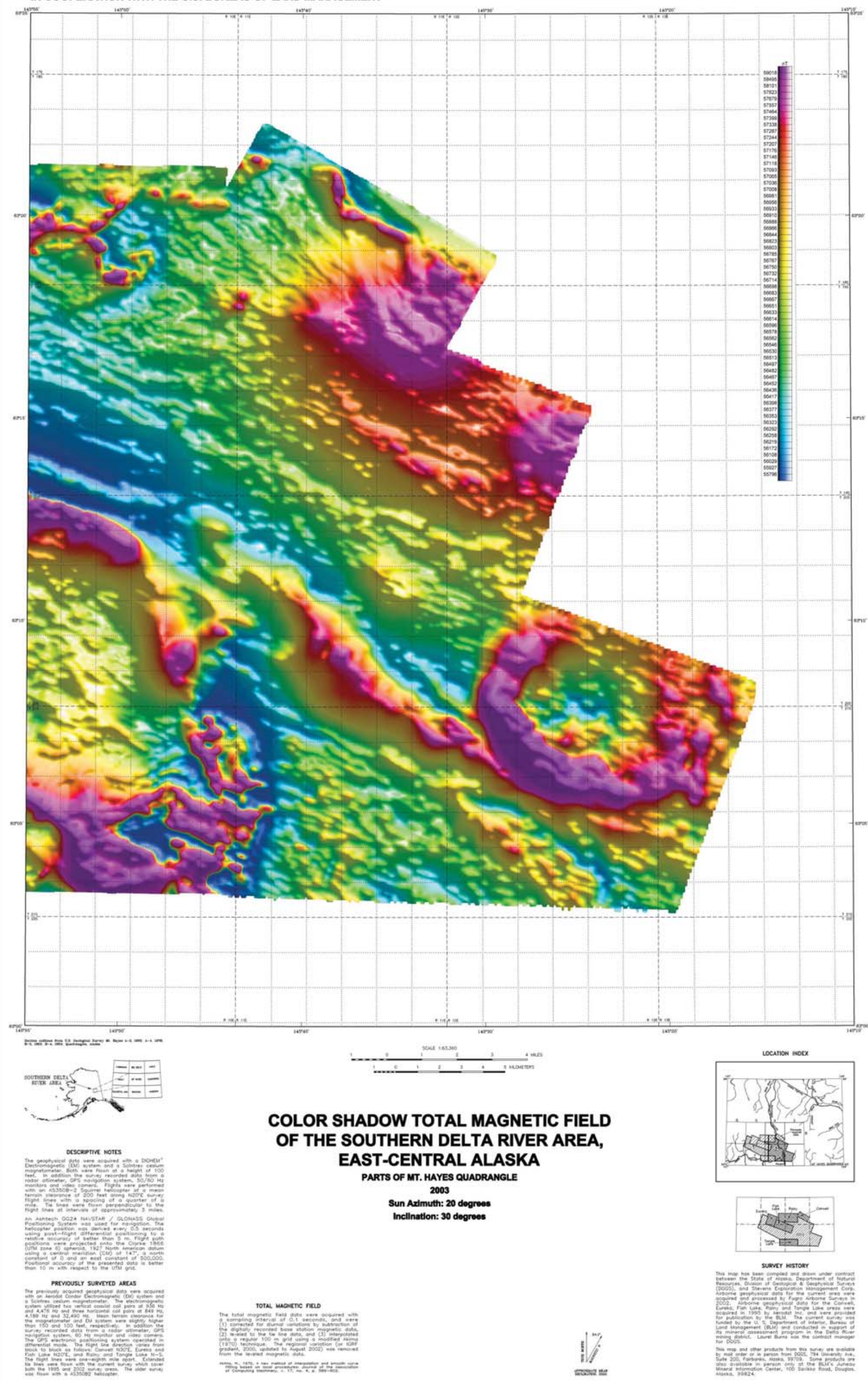




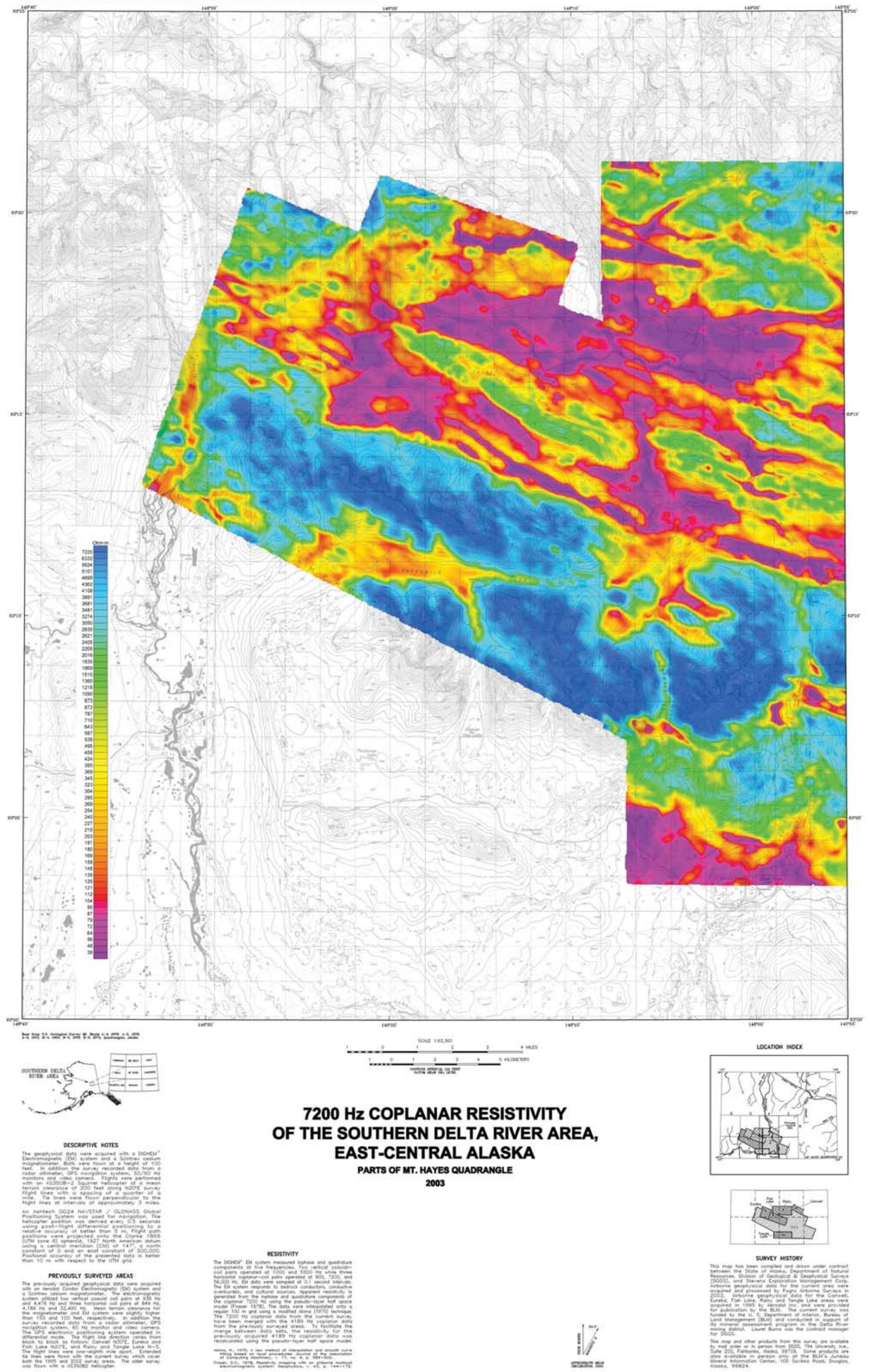




$\begin{array}{ll}\text { ALASKA DIVISION OF GEOLOGICAL \& GEOPHYSICAL SURVEYS } & \text { GEOPHYSICAL REPORT 2003 } 5 \text { Shaô } 2012 \\ \text { IN COOPERATION WITH THE U.S. BUREAU OF LAND MANAGEMENT } & \text { S }\end{array}$

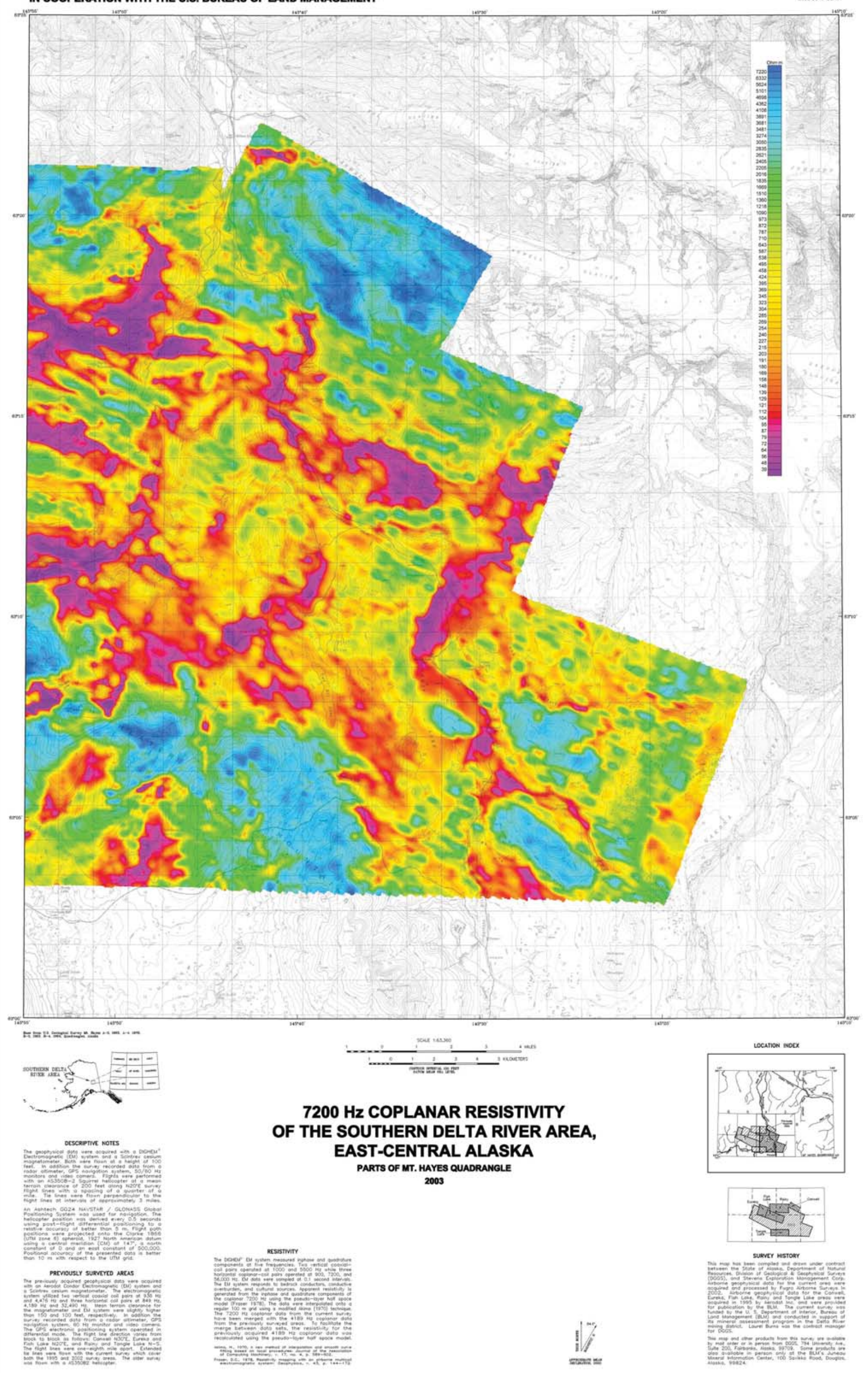




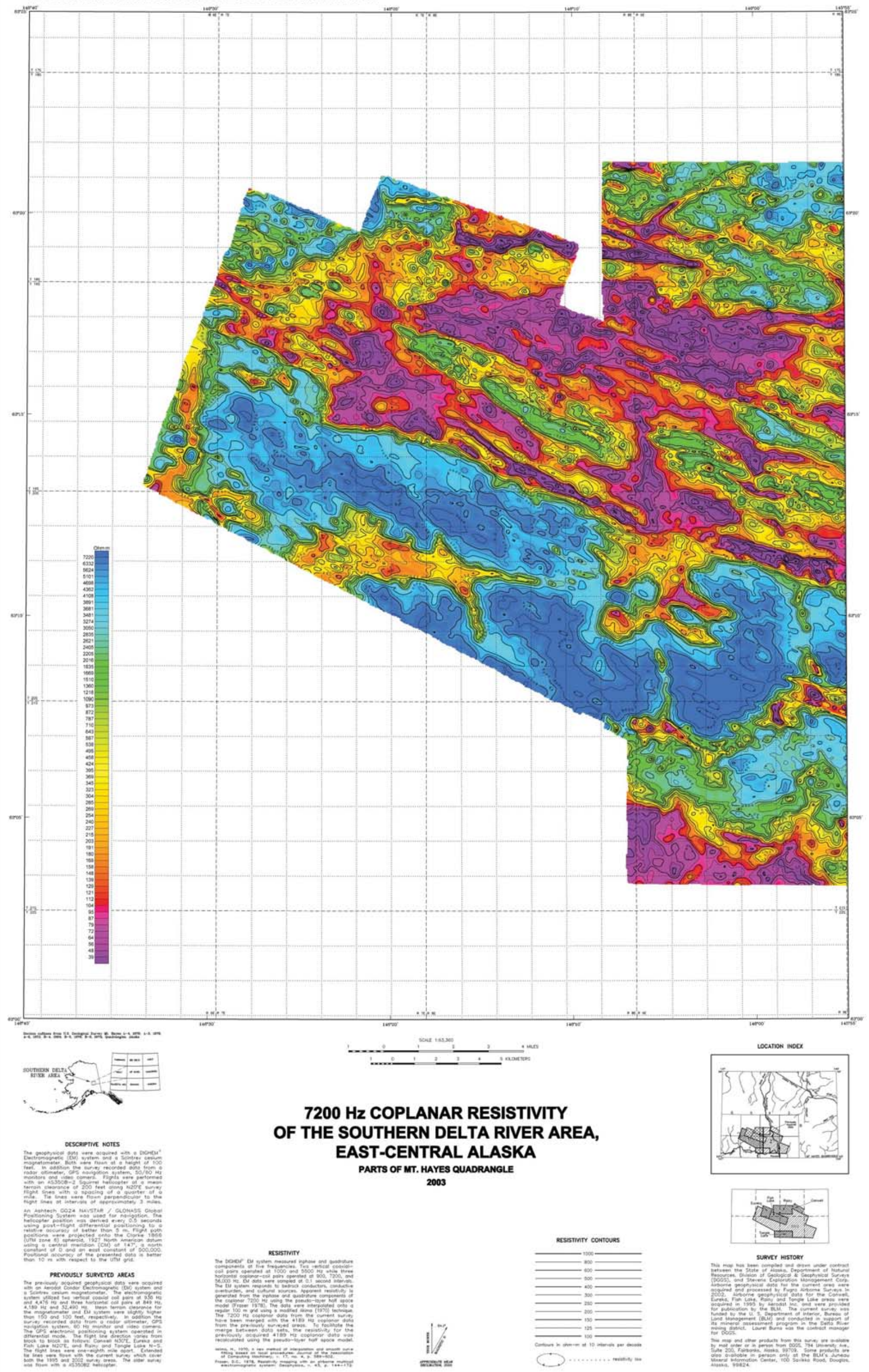




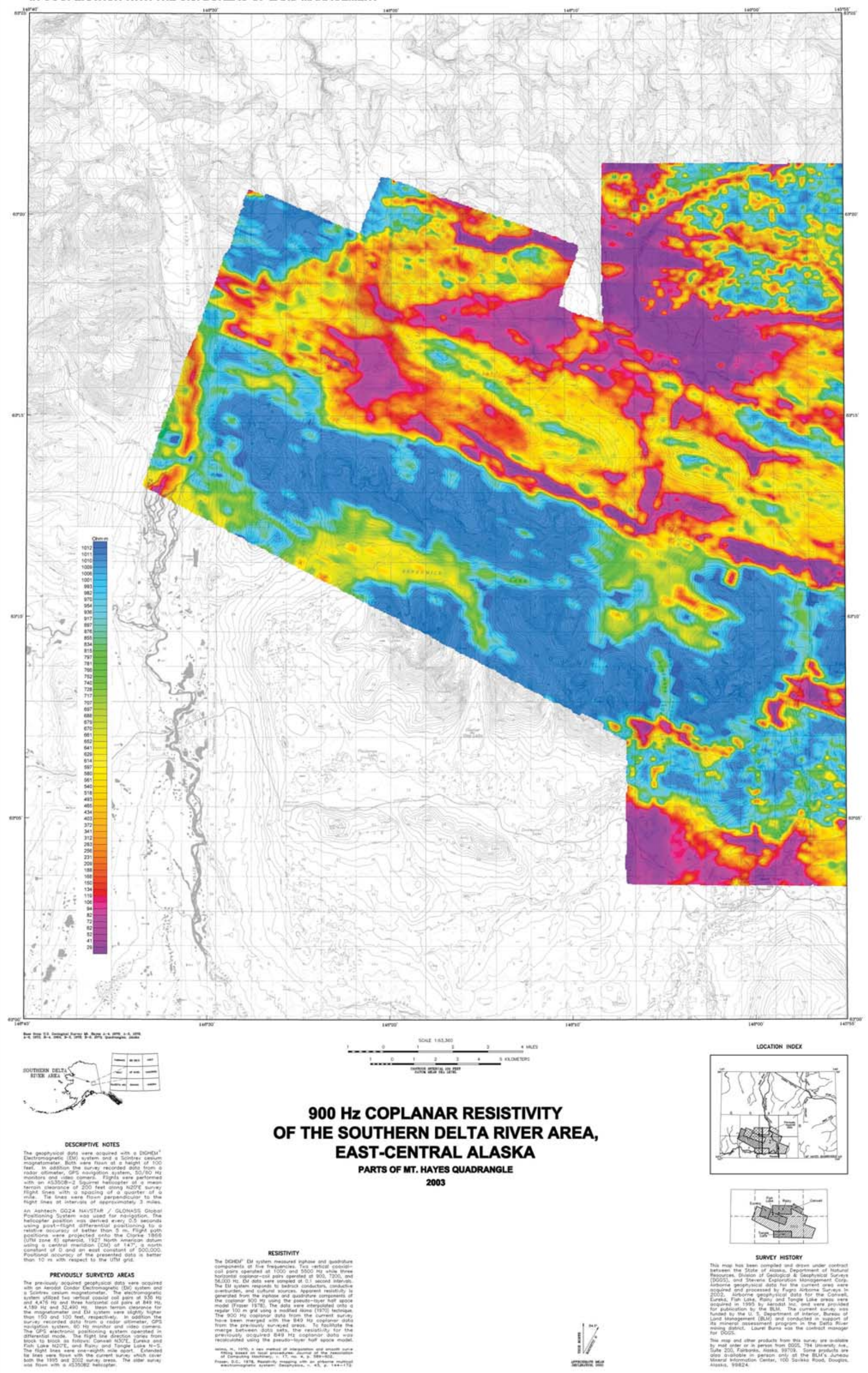




$\begin{array}{ll}\text { ALASKA DIVISION OF GEOLOGICAL \& GEOPHYSICAL SURVEYS } & \text { GEOPHYSICAL REPORT 2003 } 544 a \\ \text { IN COOPERATION WITH THE U.S. BUREAU OF LAND MANAGEMENT } & \text { Shoü 2 of } 2\end{array}$

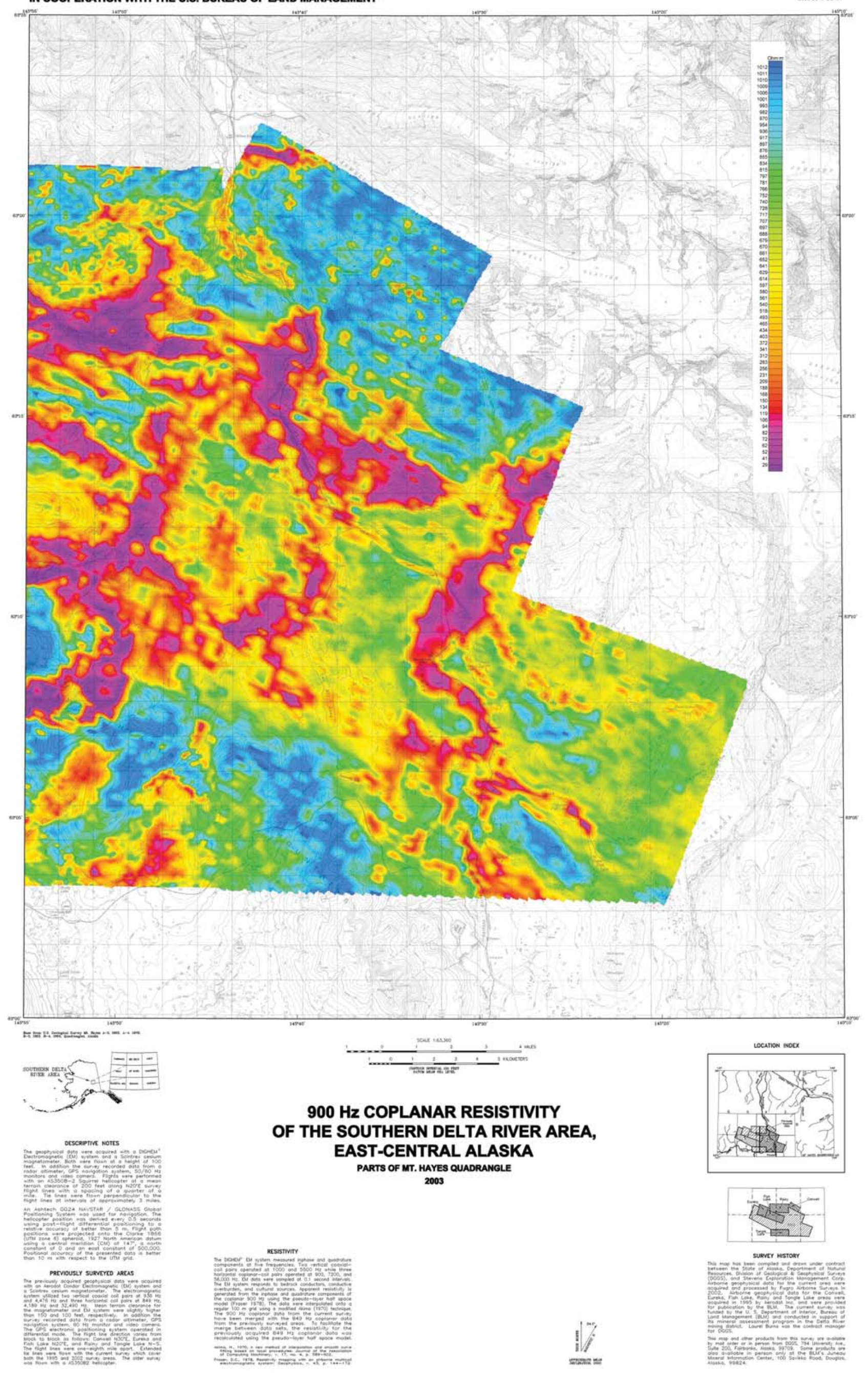




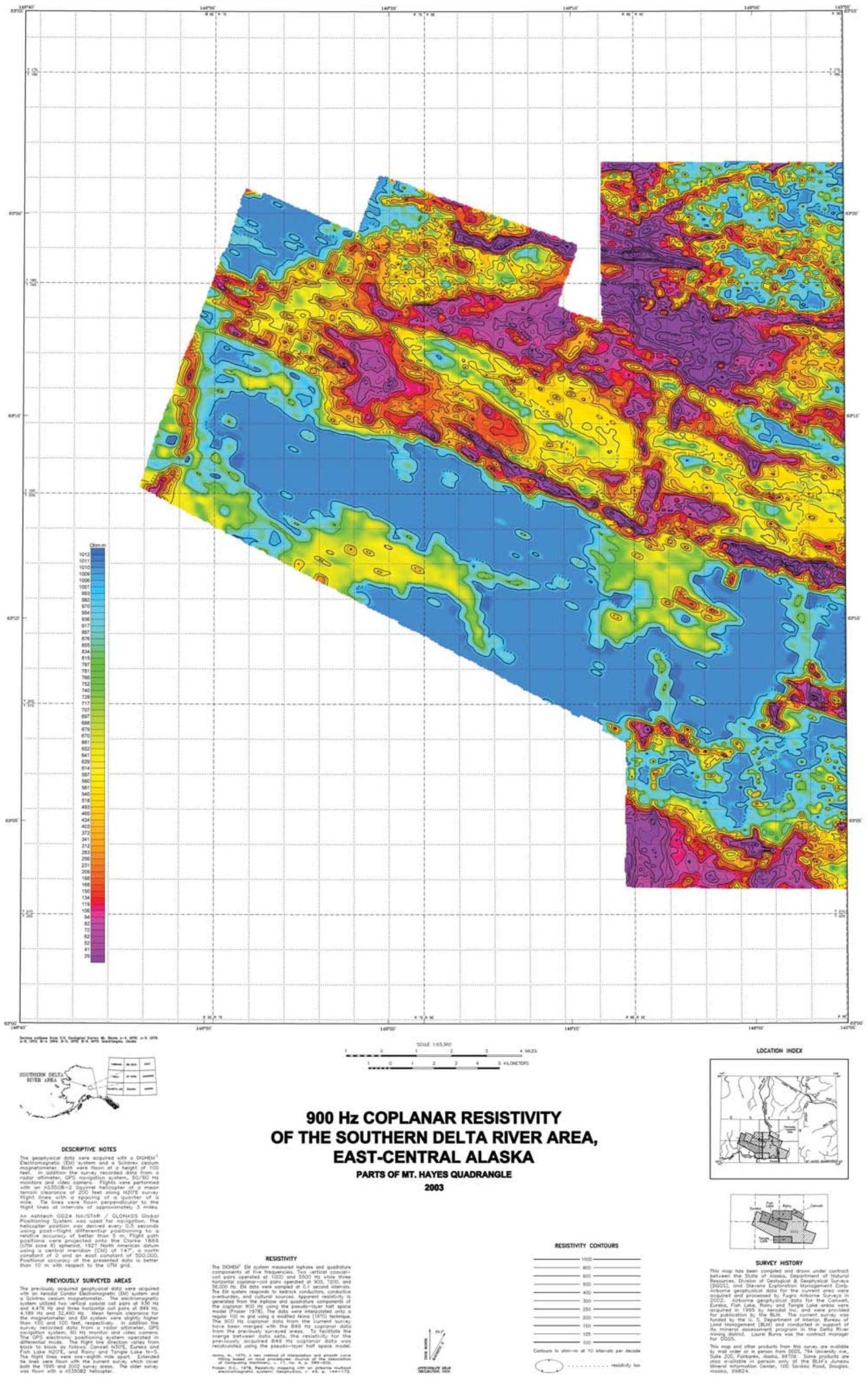




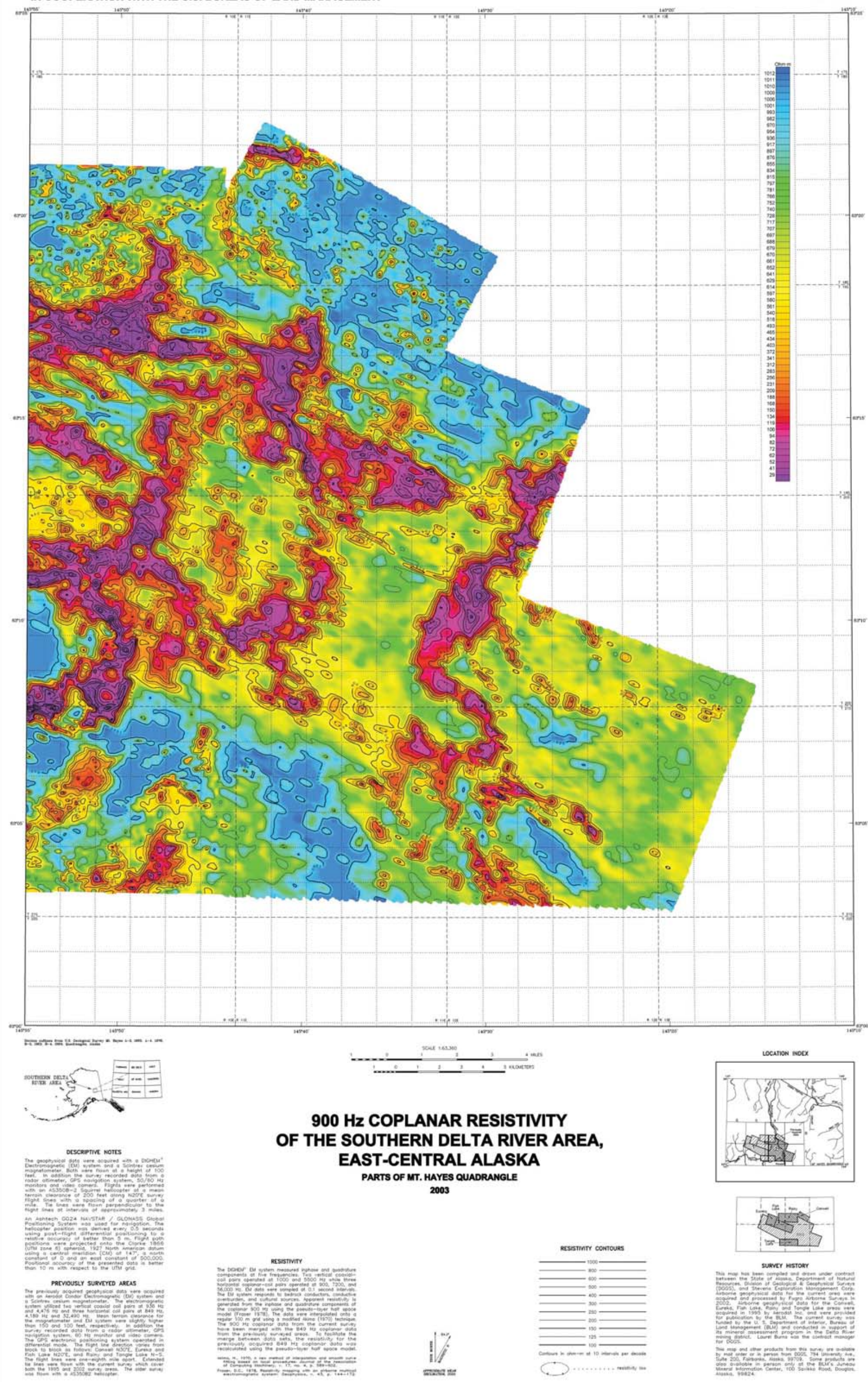




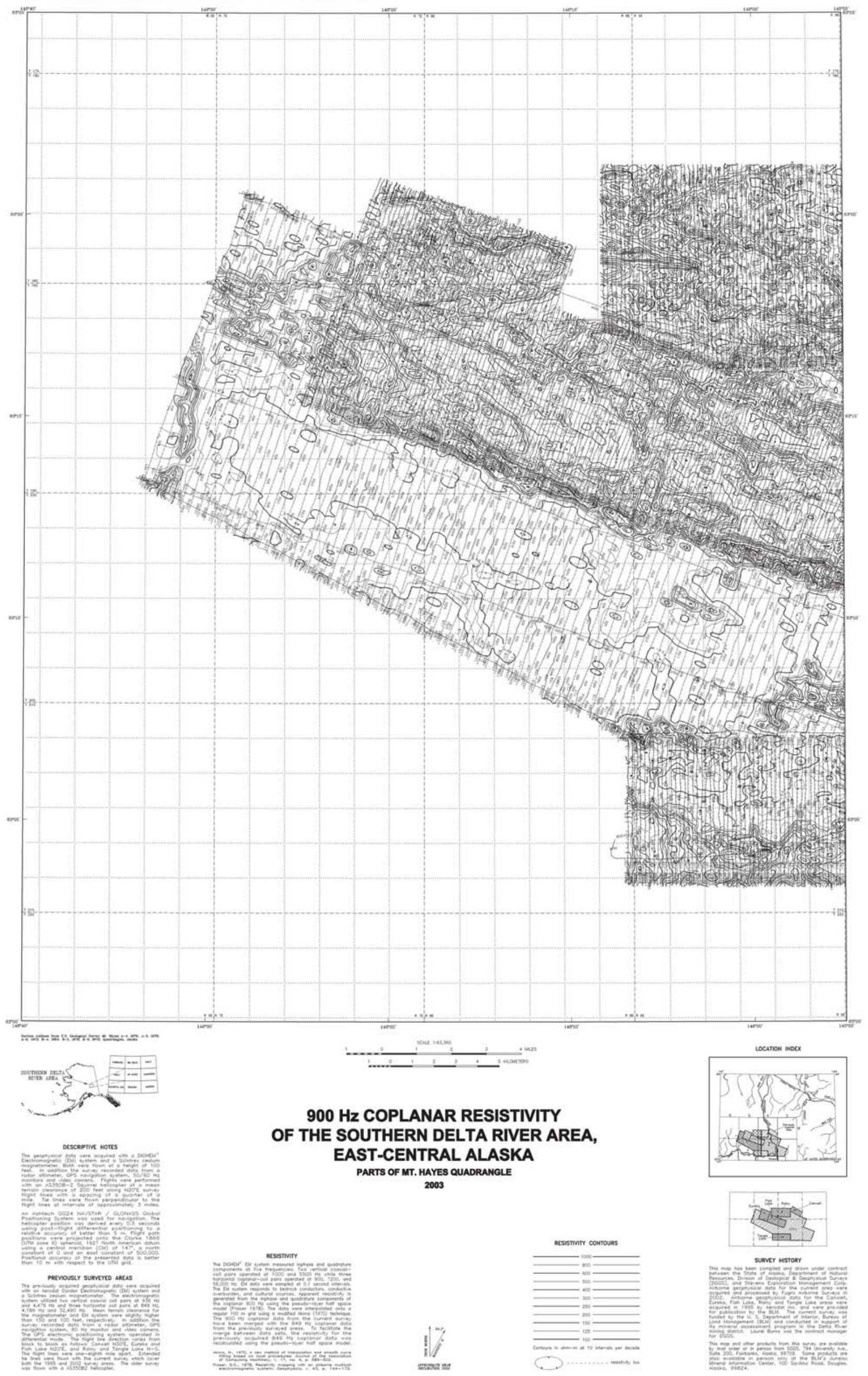




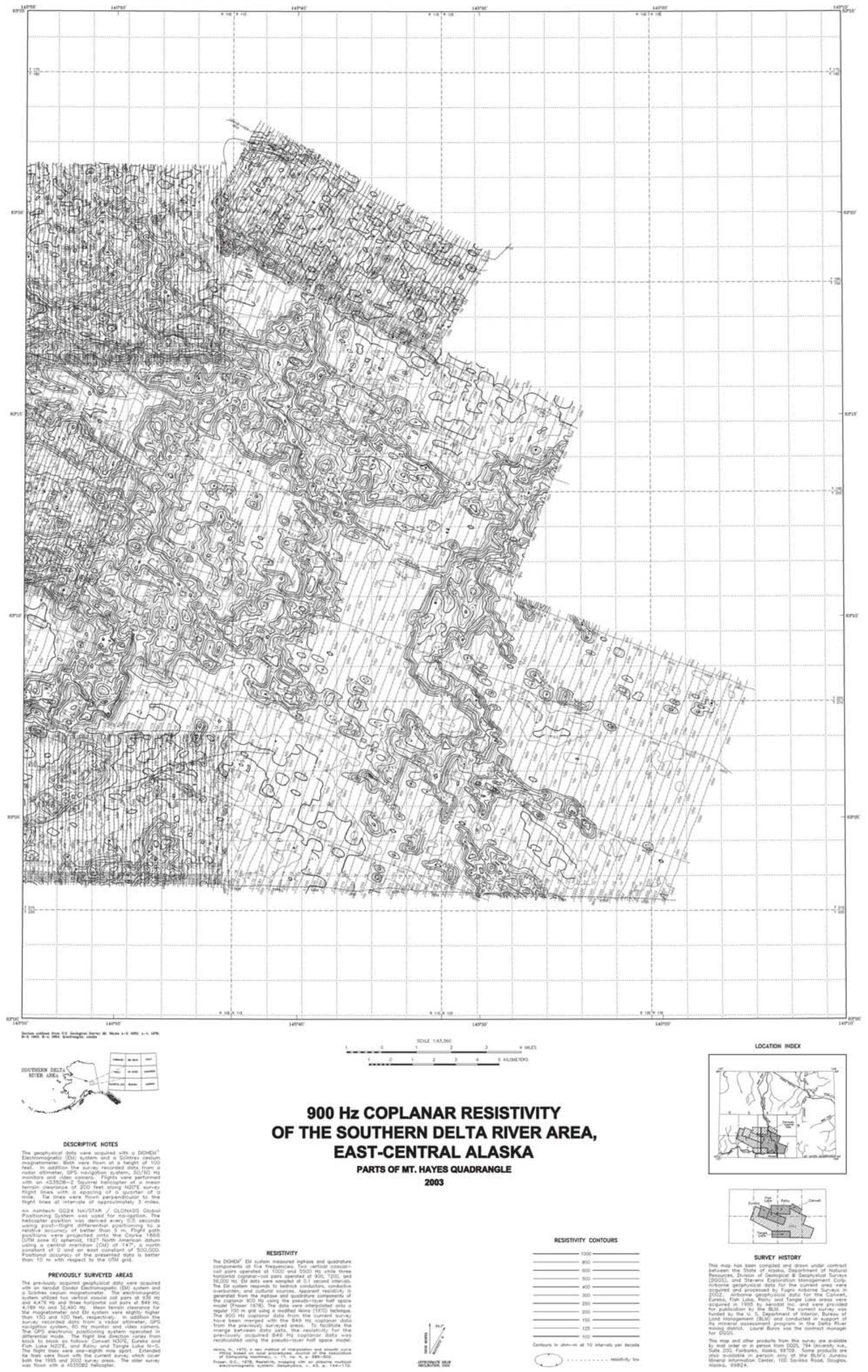




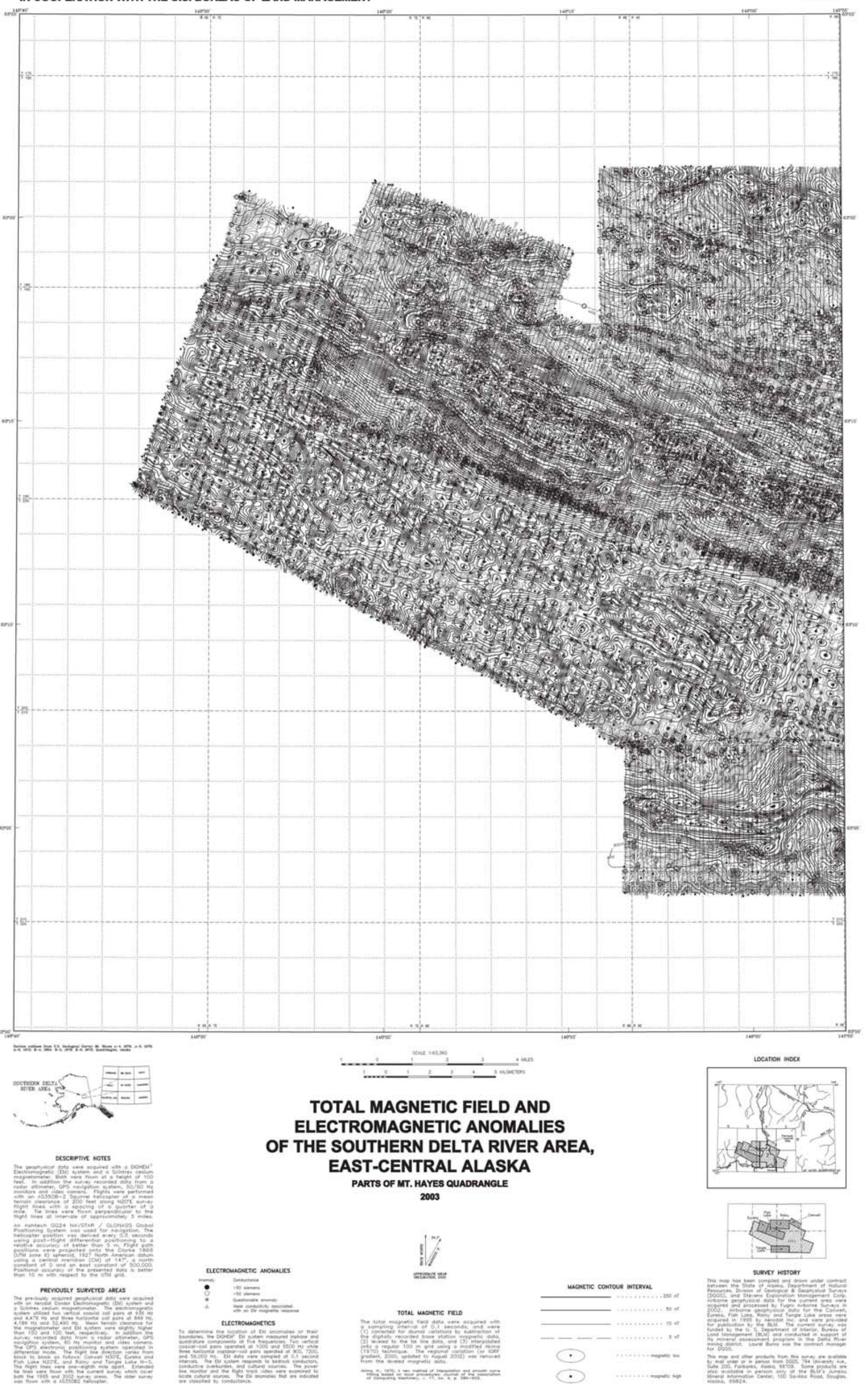




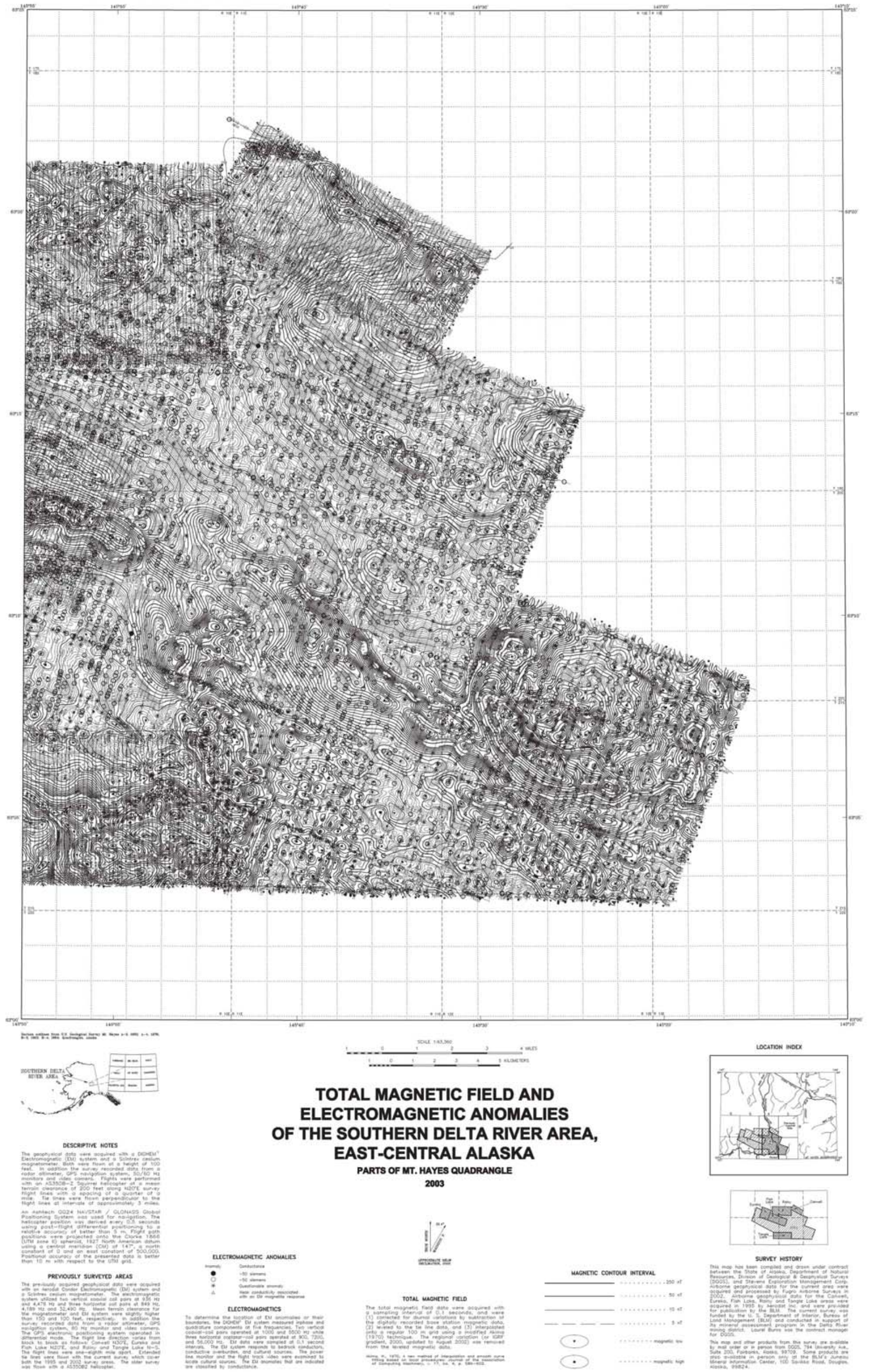




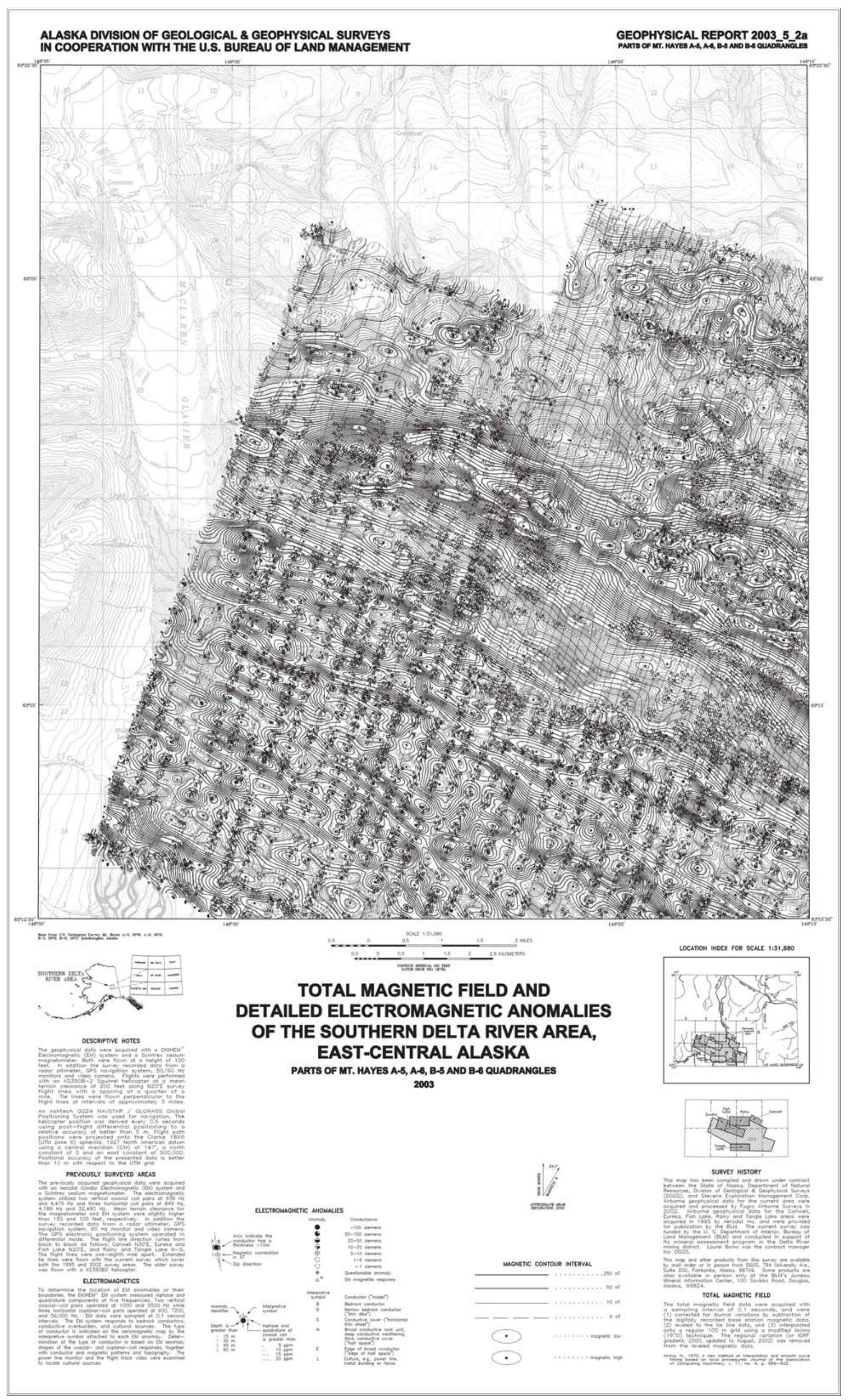




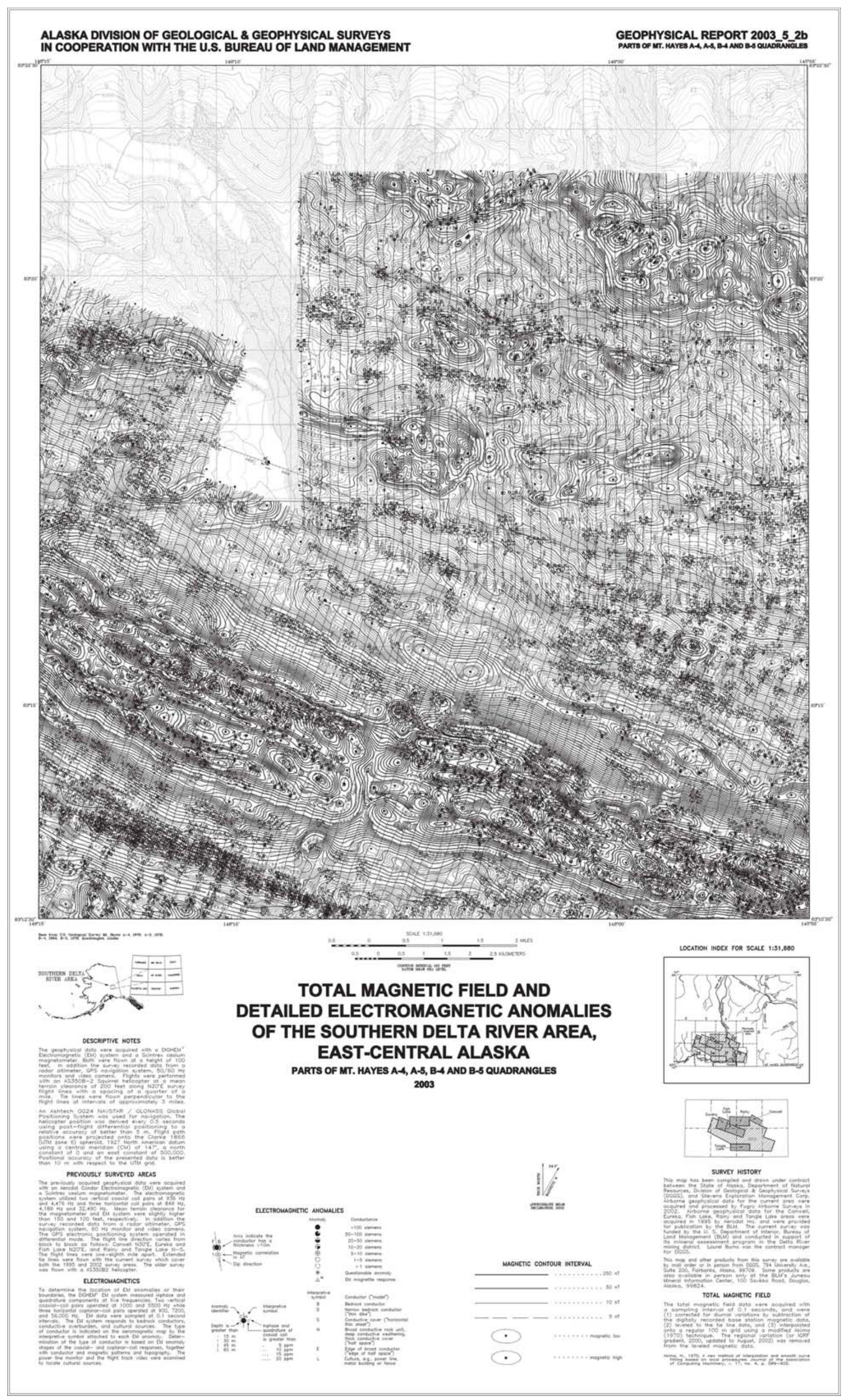




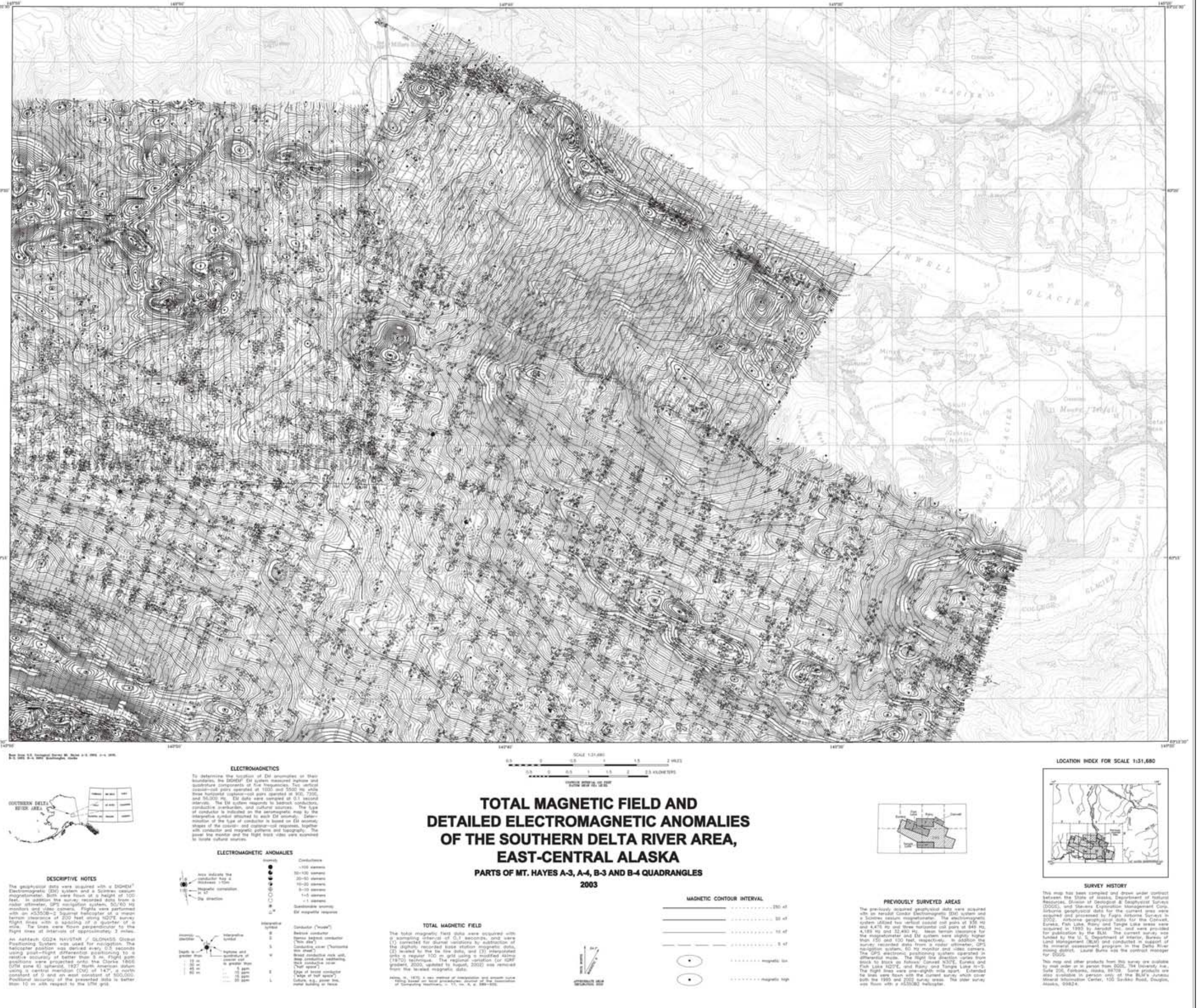




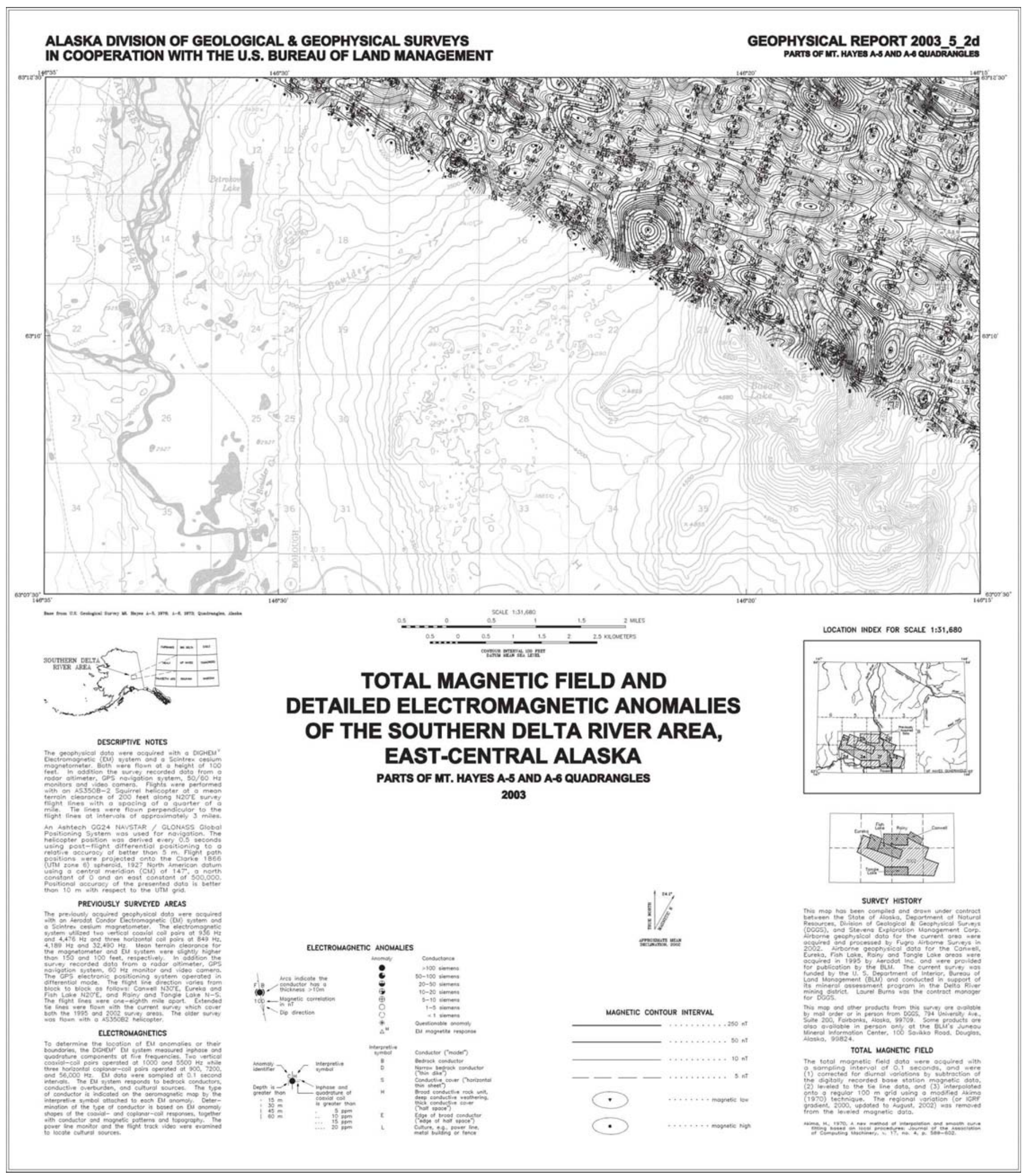




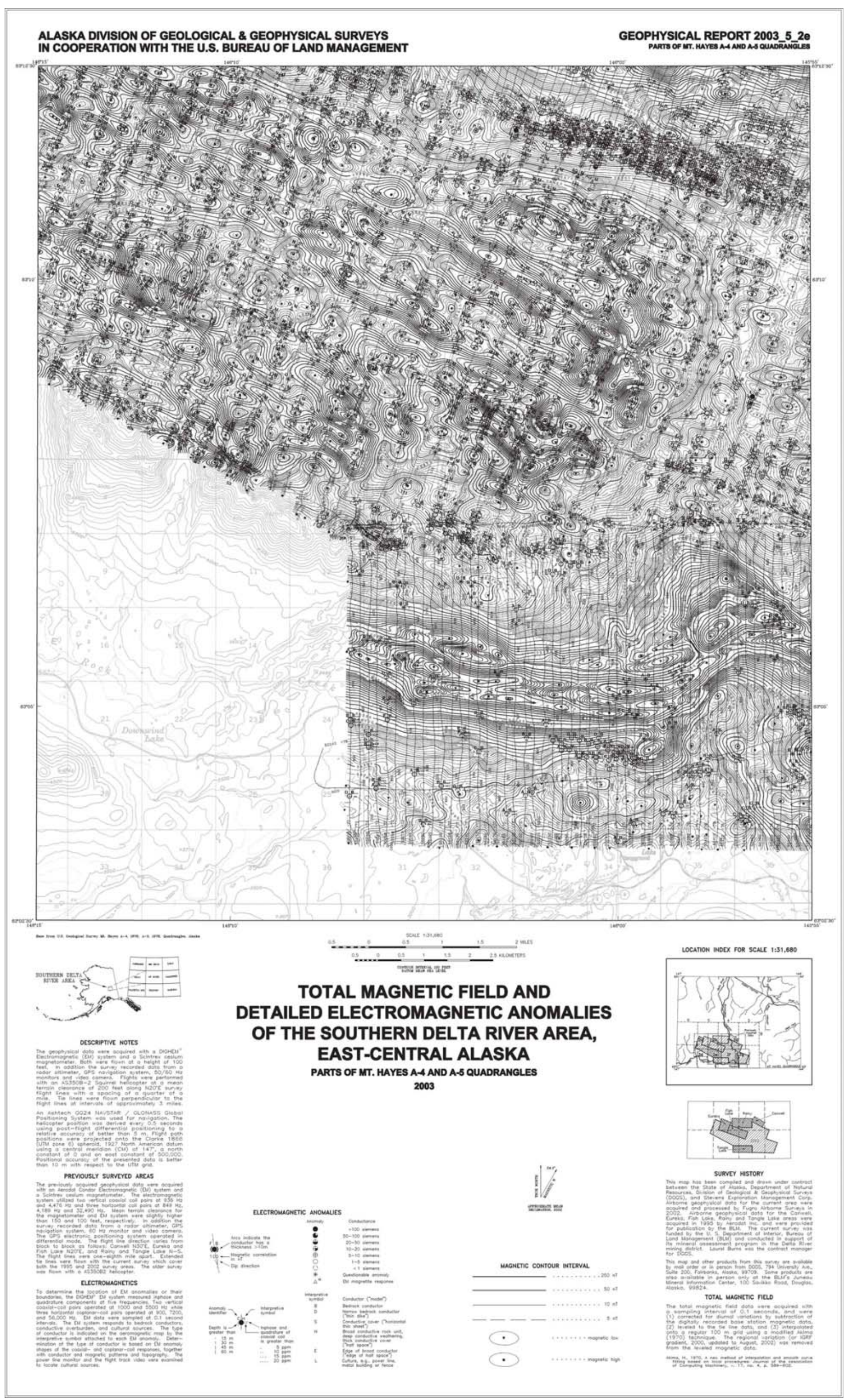




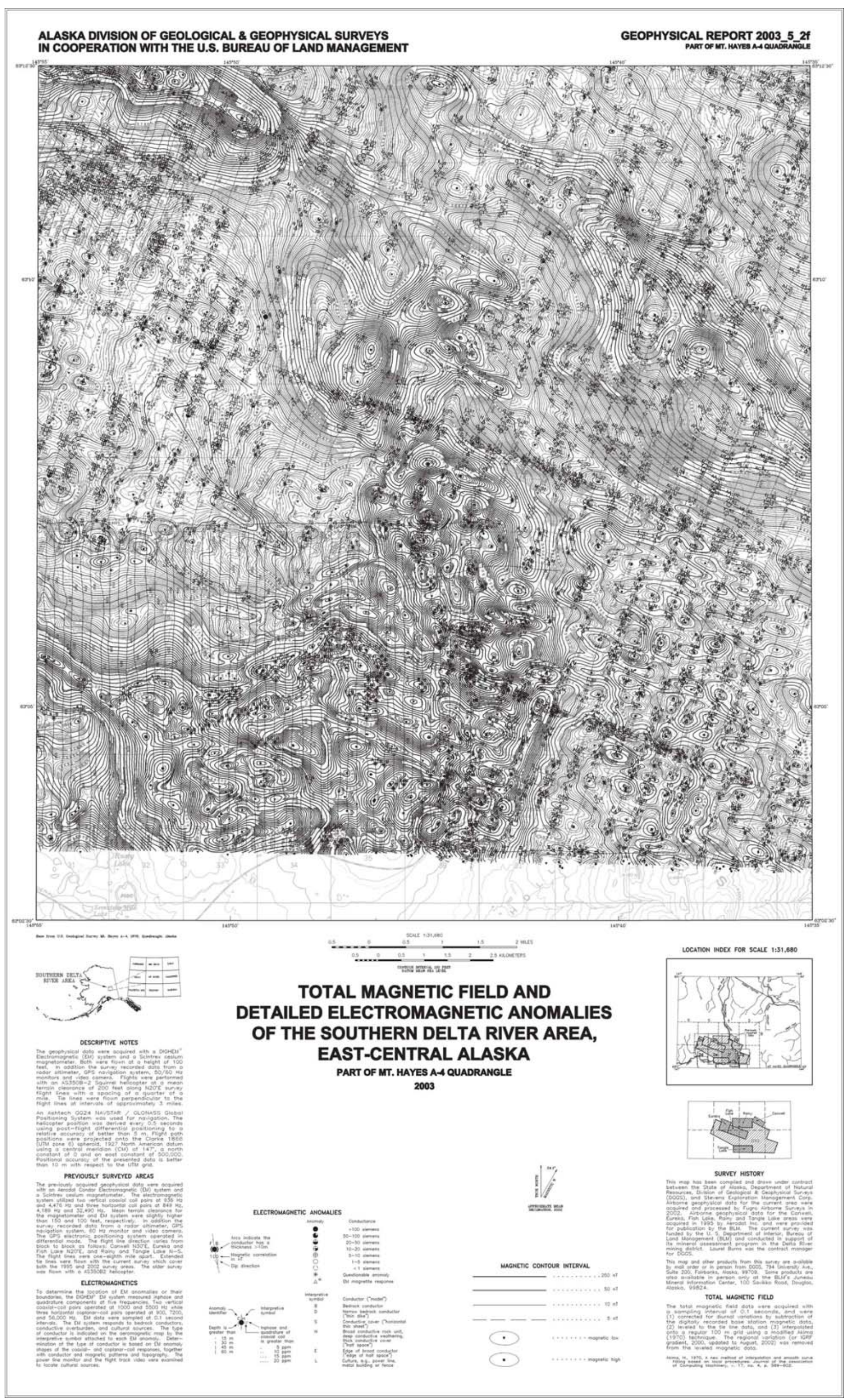




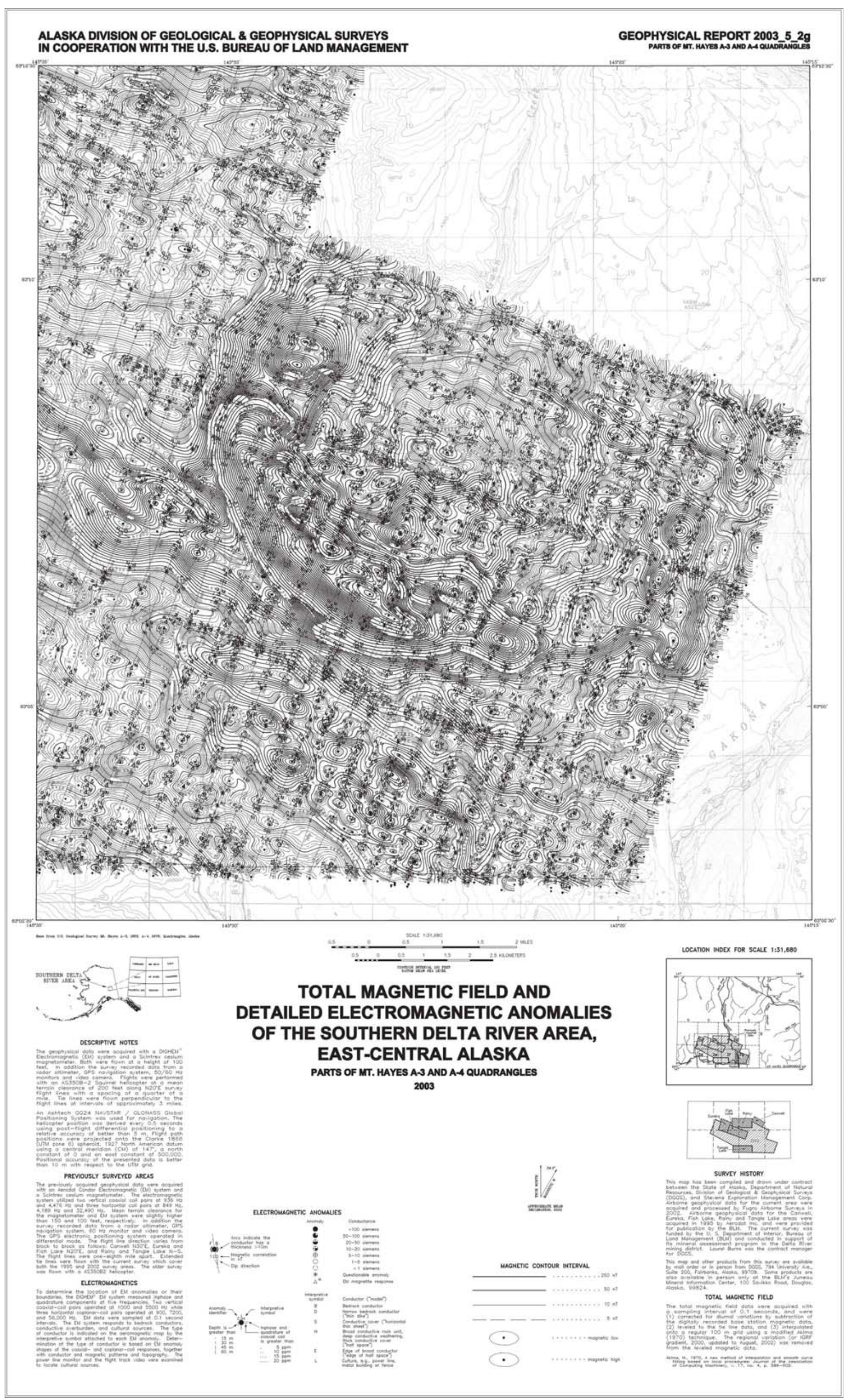




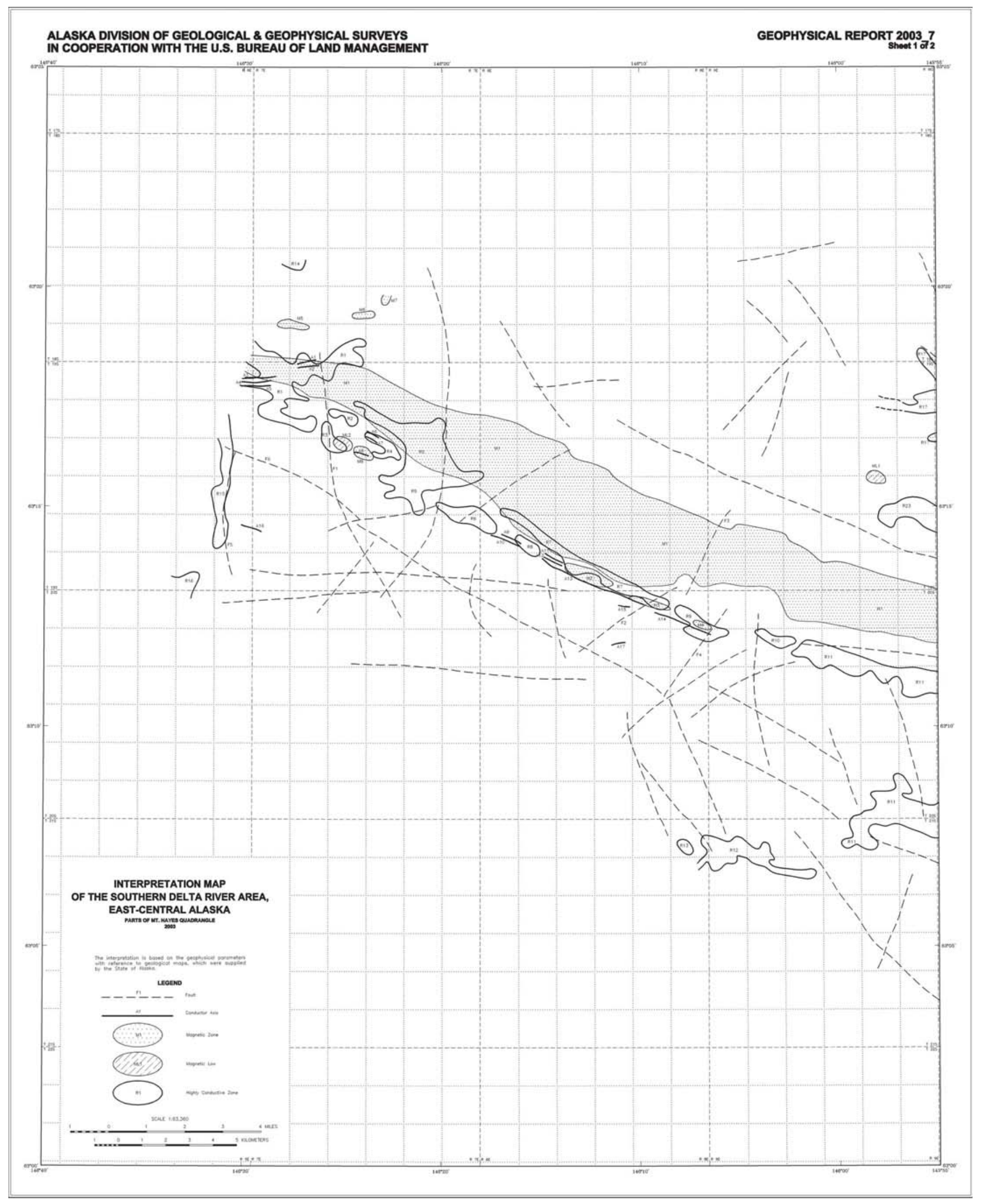




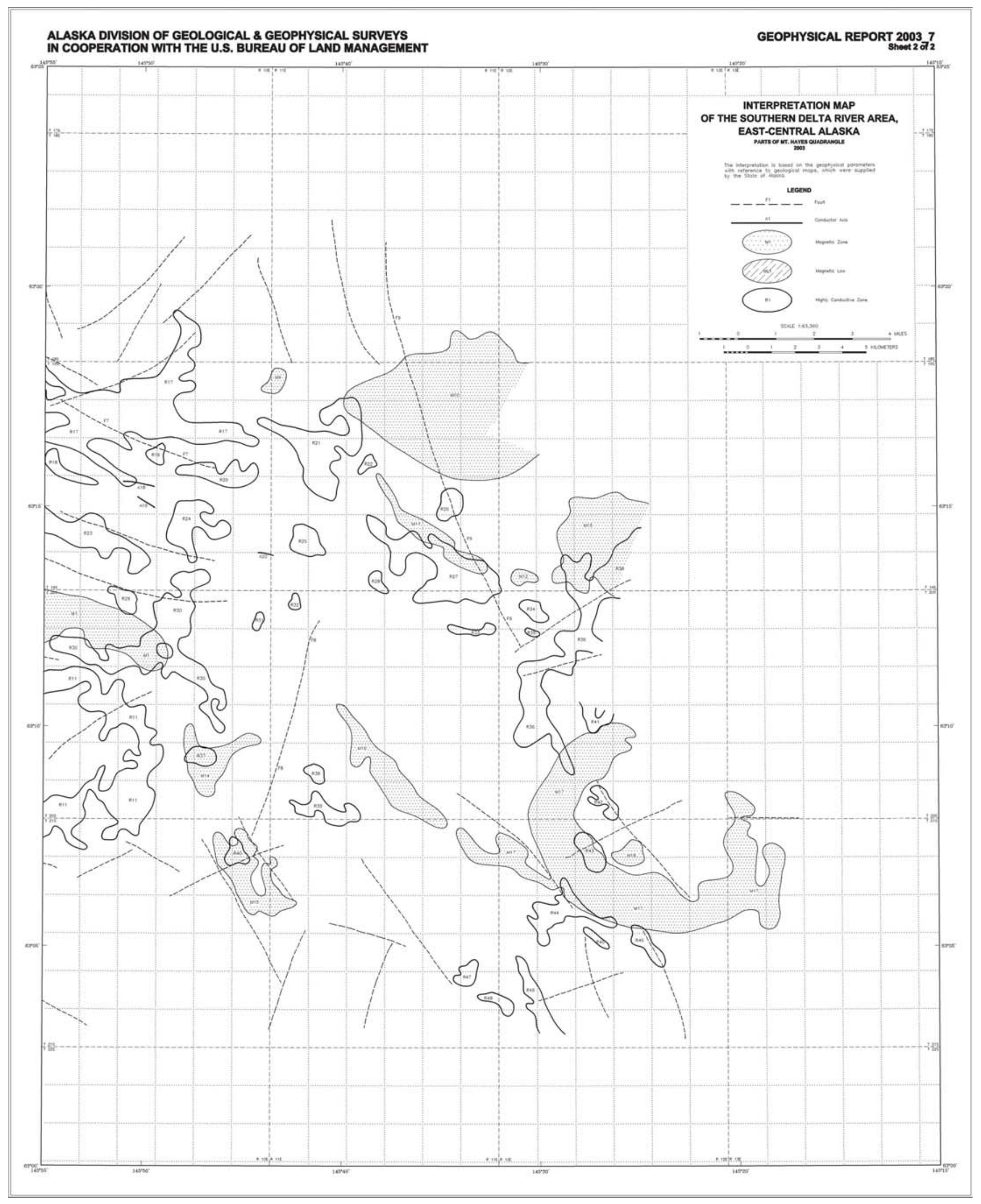




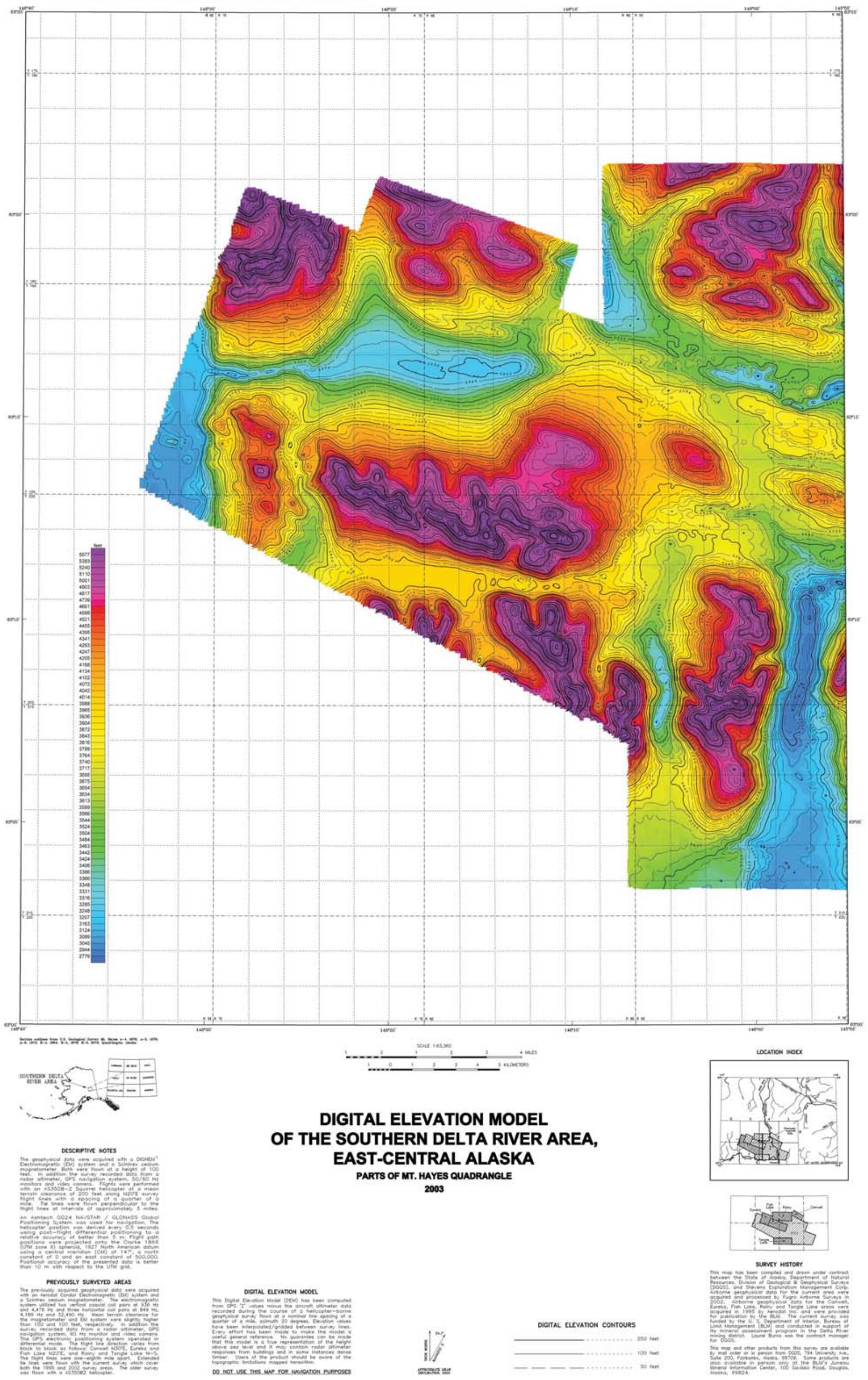




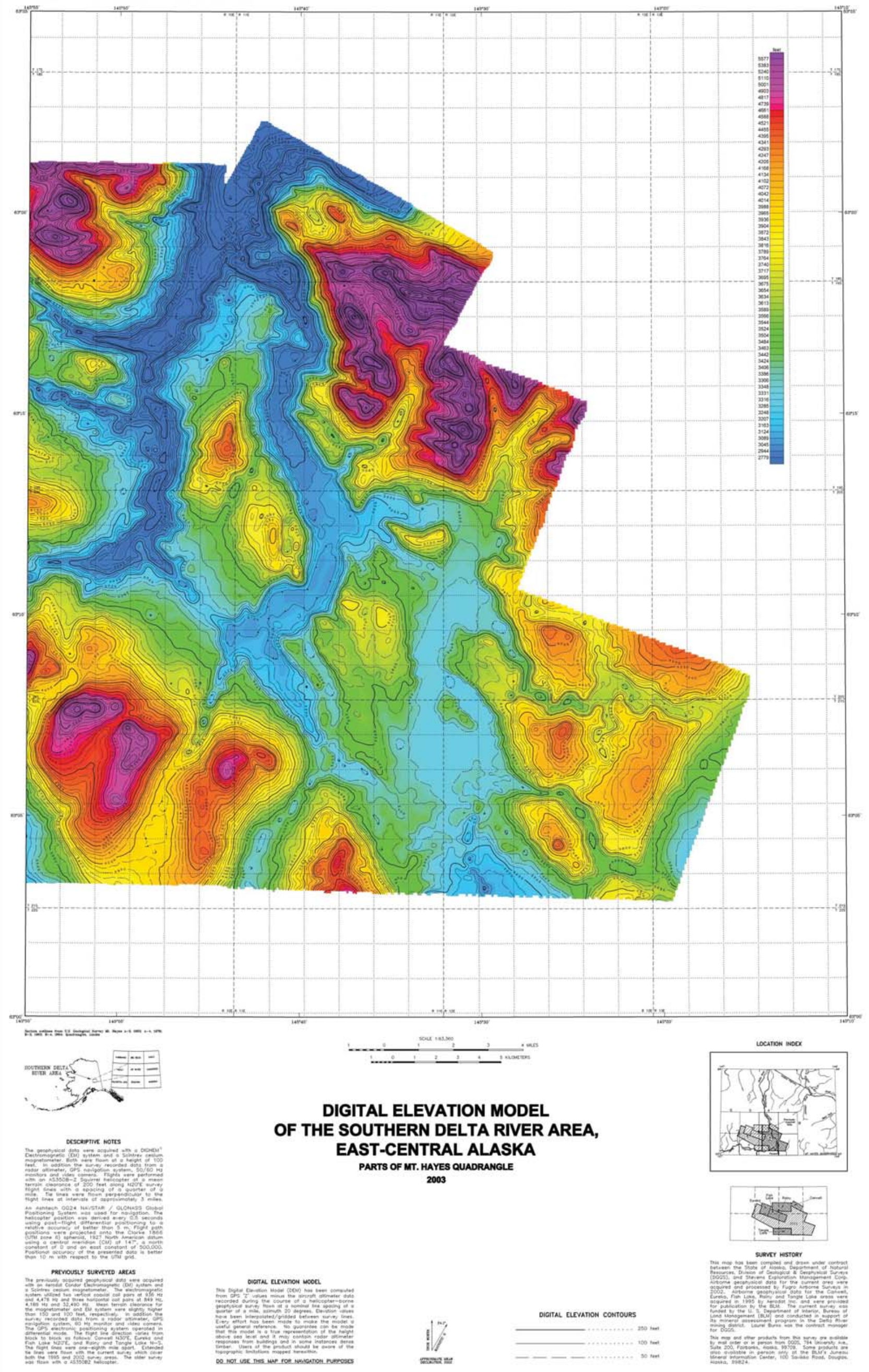

